\title{
Alleviating Pain Hypersensitivity through Activation of Type 4 Metabotropic Glutamate Receptor
}

\author{
Bruno Vilar, ${ }^{1,2}$ Jérôme Busserolles, ${ }^{3,4}$ Bing Ling, ${ }^{3,4}$ Sophie Laffray, ${ }^{1,2}$ Lauriane Ulmann, ${ }^{1,2}$ Fanny Malhaire, ${ }^{1,2}$ \\ Eric Chapuy, ${ }^{3,4}$ Youssef Aissouni, ${ }^{3,4}$ Monique Etienne, ${ }^{3,4}$ Emmanuel Bourinet, ${ }^{1,2}$ Francine Acher, ${ }^{5}$ Jean-Philippe Pin, ${ }^{1,2}$ \\ Alain Eschalier, ${ }^{3,4,6}$ and Cyril Goudet ${ }^{1,2}$ \\ ${ }^{1}$ Institut de Génomique Fonctionnelle, Centre National de la Recherche Scientifique Unité Mixte de Recherche 5203, Université de Montpellier, F-34094 \\ Montpellier, France, ${ }^{2}$ Institut National de la Santé et de la Recherche Médicale, U661, F-34094 Montpellier, France, ${ }^{3}$ Clermont Université, Université \\ d'Auvergne, Pharmacologie Fondamentale et Clinique de la Douleur, F-63000 Clermont-Ferrand, France, ${ }^{4}$ Inserm, U 1107, Neuro-Dol, F-63001 Clermont- \\ Ferrand, France, ${ }^{5}$ Laboratoire de Chimie et Biochimie Pharmacologiques et Toxicologiques, Centre National de la Recherche Scientifique Unité Mixte de \\ Recherche 8601, Université Paris Descartes, Sorbonne Paris Cité, F-75270 Paris, France, and ${ }^{6} \mathrm{CHU}$ Clermont-Ferrand, Service de pharmacologie, F-63003 \\ Clermont-Ferrand, France
}

Hyperactivity of the glutamatergic system is involved in the development of central sensitization in the pain neuraxis, associated with allodynia and hyperalgesia observed in patients with chronic pain. Herein we study the ability of type 4 metabotropic glutamate receptors (mGlu4) to regulate spinal glutamate signaling and alleviate chronic pain. We show that mGlu4 are located both on unmyelinated C-fibers and spinal neurons terminals in the inner lamina II of the spinal cord where they inhibit glutamatergic transmission through coupling to Cav2.2 channels. Genetic deletion of mGlu4 in mice alters sensitivity to strong noxious mechanical compression and accelerates the onset of the nociceptive behavior in the inflammatory phase of the formalin test. However, responses to punctate mechanical stimulation and nocifensive responses to thermal noxious stimuli are not modified. Accordingly, pharmacological activation of mGlu4 inhibits mechanical hypersensitivity in animal models of inflammatory or neuropathic pain while leaving acute mechanical perception unchanged in naive animals. Together, these results reveal that mGlu4 is a promising new target for the treatment of chronic pain.

Key words: allodynia; analgesia; GPCR; hyperalgesia; mGlu; pain

\section{Introduction}

Chronic pain is among the most debilitating and costly afflictions in North America and Europe, seriously affecting the quality of

\footnotetext{
Received March 21, 2013; revised Oct. 21, 2013; accepted 0ct. 24, 2013.

Author contributions: B.V., J.B., S.L., E.B., A.E., and C.G. designed research; B.V., J.B., B.L., S.L., L.U., F.M., E.C., Y.A., M.E., and C.G. performed research; F.A. contributed unpublished reagents/analytic tools; B.V., J.B., B.L., S.L., L.U., F.M., E.C., Y.A., E.B., J.-P.P., A.E., and C.G. analyzed data; B.V., J.B., J.-P.P., A.E., and C.G. wrote the paper.

This work was supported by Eranet Neuron and Agence Nationale de la Recherche Grants ANR-08-NEUR-006, ANR-09-MNPS-037, and 2010 ANR-MALZ105-01, La Marato de TV3, Fondation pour la Recherche Médicale (Equipe FRM DEQ20130326522), Fondation pour la Recherche sur le Cerveau, Institut UPSA de la Douleur, and Société Française d'Etude et de Traitement de la Douleur. B.V. was supported by a fellowship from the Ministère de la Recherche et de la Technologie. We thank Yves Le Feuvre and Frédéric Nagy from Institut National de la Santé et de la Recherche Médicale U862 and Federica Bertaso from IGF Centre National de la Recherche Scientifique Unité Mixte de Recherche 5203 for their technical help on electrophysiology on slices; Julien Cau from the Montpellier RI0 Imaging facility of campus Centre National de la Recherche Scientifique Arnaud de Villeneuve and Delphine Rigault from Centre National de la Recherche Scientifique Unité Mixte de Recherche 8601 for the synthesis of LSP4-2022; David Hampson for kindly providing mGlu4KO mice; and Gregory Stewart and Ebba L. Lagerqvist from IGF Centre National de la Recherche Scientifique Unité Mixte de Recherche 5203 for critical reading of the manuscript. The IGF belongs to the Laboratories of Excellence, Ion Channel Science and Therapeutics, and EpiGenMed.

The authors declare no competing financial interests.

Correspondence should be addressed to either of the following: Dr. Cyril Goudet, Institut de Génomique Fonctionnelle, Centre National de la Recherche Scientifique Unité Mixte de Recherche 5203, Institut National de la Santé et de la Recherche Médicale U661, Université de Montpellier, 141, Rue de la Cardonille, F34094 Montpellier cedex 5, France, E-mail: cyril.goudet@igf.cnrs.fr; or Prof. Alain Eschalier, Institut National de la Santé et de la Recherche Médicale Unité Mixte de Recherche 1107, Pharmacologie Fondamentale et Clinique de la Douleur, Université d'Auvergne, 28, Place Henri Dunant, F63001 Clermont-Ferrand cedex 1, France, E-mail: alain.eschalier@udamail.fr. DOI:10.1523/JNEUROSCI.1221-13.2013

Copyright $\odot 2013$ the authors $\quad 0270-6474 / 13 / 3318951-15 \$ 15.00 / 0$
}

life of $>19 \%$ of adult Europeans (Verhaak et al., 1998; Ospina and Harstall, 2002; Breivik et al., 2006; Bouhassira et al., 2008). With regard to neuropathic pain, the burden of disease is further worsened by the large proportion of patients whose treatment does not offer significant relief (Micó et al., 2006; Finnerup et al., 2010), highlighting the crucial need of progress in the management of pain. Comprehensive understanding of the cellular and molecular mechanisms involved in chronic pain may in turn lead to the development of effective targeted therapies.

The blockade of increased glutamatergic activity may represent a pivotal means of reducing chronic pain but await a clearer identification of adequate targets. Central sensitization of the pain neuraxis is associated with hyperexcitability of the glutamatergic system and leads to the development of the evoked pain symptoms, allodynia and hyperalgesia (Latremoliere and Woolf, 2009). At the synaptic level, glutamate activity is mediated through two classes of receptors, ionotropic receptors (iGluRs), which are ligand-gated ion channels responsible for the fast synaptic response, and metabotropic receptors (mGluRs), which are G-protein-coupled receptors that modulate synaptic activity. Both iGluRs and mGluRs are involved in the induction and the maintenance of central sensitization.

Given that mGluRs are expressed all along the pain neuraxis where they modulate the perception of pain (Varney and Gereau, 2002; Neugebauer, 2007; Goudet et al., 2009; Chiechio and Nico- 
letti, 2011), the selective targeting of mGluRs to modulate synaptic activity could constitute a viable alternative to the direct blockade of synaptic glutamate transmission by iGluRs antagonists. Eight mGluRs have been identified so far (mGlu1-mGlu8) and classified in three groups (Niswender and Conn, 2010; Nicoletti et al., 2011). Group I mGluRs (mGlu1, mGlu5) are postsynaptic receptors that positively modulate neuronal excitability, whereas Group II (mGlu2-mGlu3) and Group III (mGlu4, mGlu6-mGlu8) are mainly presynaptic receptors that exert a negative retrocontrol on neurotransmission. The role of Group III mGluRs in pain has been less studied than the other groups, but their ability to reduce hyperalgesia in animal models of chronic pain (Fisher et al., 2002; Mills et al., 2002; Chen and Pan, 2005; Goudet et al., 2008), and to regulate neurotransmission in the dorsal horn of spinal cord (Chen and Pan, 2005; Zhang et al., 2009; Carlton et al., 2011; Wang et al., 2011), reveals their potential for the development of analgesics. However, the precise role and contribution of each of the Group III subtypes at the spinal cord level on pain modulation remain to be elucidated.

In the present study, we focused our attention on mGlu4. We have determined its precise localization in sensory neurons and spinal interneurons. We have evaluated its modulation of glutamatergic neurotransmission on spinal cord slices of naive or inflamed animals. Then, combining selective pharmacological and genetic tools in behavioral studies, we highlighted the key role of presynaptic mGlu4 receptors in the modulation of mechanical hypersensitivity in inflammation or nerve injury, thus exemplifying the significant potential of mGlu4 receptors as a therapeutic target for the treatment of chronic pain.

\section{Materials and Methods}

\section{Animals}

Animal care and experiments were performed in accordance with the Committee for Research and Ethical Issues of the International Association for the Study of Pain (Zimmermann, 1983).

Male Sprague Dawley rats were purchased from Charles River, and C57BL/6 mice from Elevage Janvier. Homozygous mGlu4KO mice and wild-type littermates were generated from crosses between heterozygous animals. mGlu4KO mice were first described by Pekhletski et al. (1996), and their genotyping was performed according to the method described by Pitsch et al. (2007). Animals were housed under controlled environmental conditions $\left(22^{\circ} \mathrm{C}\right.$; $55 \%$ humidity) and kept under a $12 / 12 \mathrm{~h} \mathrm{light/}$ dark cycle, with food and water ad libitum for a week before start the experiments to acclimatize.

\section{Immunofluorescence}

The mice were anesthetized with pentobarbital (100 mg/kg,i.p.), and tissues were fixed via transcardiac perfusion of $4 \%$ paraformaldehyde in PBS and postfixed overnight. Transverse lumbar spinal cords slices of 30 $\mu \mathrm{m}$ were cut with a vibratome.

Transverse sections of mouse spinal cords were preincubated for $1 \mathrm{~h}$ in PBS containing $0.3 \%$ Triton $\mathrm{X}-100$ and 5\% donkey serum and then immunostained overnight at $4^{\circ} \mathrm{C}$ in the same buffer containing primary antibodies. After three washes, sections were incubated in a conjugated secondary donkey antibody for $2 \mathrm{~h}$ at room temperature.

The following antibodies were purchased from commercial sources: rabbit anti-mGlu4a (Invitrogen, 51-3100; 1/100), rabbit anti-PKC $\gamma$ (Santa Cruz Biotechnology, sc-166385; 1/500), mouse anti-NF200 (Sigma, clone N52, N0142; 1/400), mouse anti-CGRP (Santa Cruz Biotechnology, sc-8857; 1/50), guinea pig anti-VGLUT3 (Millipore, AB5421; 1/5000), rat antiSubstance P (Medimabs, NC1/34; 1/25), IB4 FITC conjugate (Sigma, L 2895; 1/100), mouse anti-bassoon (Enzo Life Sciences, ADI-VAM-PS003; 1/1000), mouse anti-synaptophysin (Sigma, S5768; 1/1000), donkey anti-rabbit Alexa-546 (Invitrogen), donkey anti-rabbit DyLight 488 (Jackson ImmunoResearch Laboratories; 1/500), donkey anti-mouse FITC (Jackson ImmunoResearch Laboratories; 1/500), donkey anti-guinea pig DyLight 488
(Jackson ImmunoResearch Laboratories; 1/500), and donkey anti-rat FITC (Jackson ImmunoResearch Laboratories; 1/500).

Immunostained sections were mounted with ProLong Gold (Invitrogen), viewed with a Bio-Rad MRC 1024 or a Zeiss LSM510 META confocal microscope, and images were analyzed with ImageJ.

\section{Rhizotomy}

Mice were anesthetized with an intraperitoneal injection of ketamine/ xylazine $(100 \mathrm{mg} / \mathrm{kg}$ and $10 \mathrm{mg} / \mathrm{kg}$, respectively). A $1-\mathrm{cm}-$ long incision was made in the skin of the back, and the L4 spinal cord segment was exposed by laminectomy. A pool was formed around the exposed spinal segment with the incised skin and filled with artificial CSF (ACSF). A small hole was made in the dura overlying the dorsal root branches that enter the L4 lumbar segment. A fine forceps (Dumont \#55) was introduced subdurally, and the dorsal root branches were resected with micro-scissors. To minimize scar formation on the spinal tissue, a piece of artificial dura (Gore Preclude MVP Dura Substitute, W.L. Gore and Associates) was used to cover the laminectomy site. Musculature and skin were then closed with sterile $4-0$ Vicryl sutures. Animals were given subcutaneous injections of $0.9 \% \mathrm{NaCl}$ sterile solution to prevent dehydration and kept on a heating pad until fully awake. Animals were housed in individual cages and killed $15 \mathrm{~d}$ later for immunohistochemical analysis.

\section{Spinal cord transmission}

Spinal cord slice preparation. Young C57BL/6 mice (14-19 d old) were anesthetized with isoflurane, and the lumbar segment of spinal cord at L4 to L6 level was rapidly removed and immediately placed in an ice-cold dissection solution presaturated with $95 \% \mathrm{O}_{2}$ and $5 \% \mathrm{CO}_{2}$. This solution contained (in $\mathrm{mM}$ ) as follows: glucose, $25 ; \mathrm{NaCl}, 101 ; \mathrm{KCl}, 3.8 ; \mathrm{MgCl}_{2}$, 18.7; $\mathrm{MgSO}_{4}, 1.3 ; \mathrm{KH}_{2} \mathrm{PO}_{4}, 1.2 ; \mathrm{HEPES}, 10 ; \mathrm{CaCl}_{2}, 1 ; \mathrm{pH}$ 7.3. The tissue was then placed in a groove formed in an agarose block and glued onto the metal block of a vibratome (Vibratome 3000). Transverse spinal cord slices were cut to $300 \mu \mathrm{m}$ in the ice-cold dissection solution and then preincubated in ACSF oxygenated with $95 \% \mathrm{O}_{2}$ and $5 \% \mathrm{CO}_{2}$ at room temperature for at least $1 \mathrm{~h}$ before being transferred to the recording chamber. The ACSF contained (in $\mathrm{mM}$ ) as follows: glucose, 10; $\mathrm{NaCl}$, 130.5; KCl, 2.4; $\mathrm{MgSO}_{4}, 1.3 ; \mathrm{KH}_{2} \mathrm{PO}_{4}, 1.2$; HEPES, $1.25 ; \mathrm{CaCl}_{2}, 2.4$; $\mathrm{NaHCO}_{3}, 19.5 ; \mathrm{pH}$ 7.3. In the recording chamber, the slice was continuously perfused with ACSF solution at $31^{\circ} \mathrm{C}$. In the experiments performed on spinal cord of inflamed animals, inflammation was induced by bilateral injections of $15 \mu \mathrm{l}$ of complete Freund's adjuvant (CFA) $24 \mathrm{~h}$ before the slice preparation.

Electrophysiological recording. Recordings of postsynaptic currents were performed using the whole-cell voltage-clamp method (holding potential $-70 \mathrm{mV}$ ). The spinal lamina II has a distinct translucent appearance and can easily be distinguished under a microscope. Lamina II neurons in the spinal slice were visualized with infrared optics using an X40 0.80 water-immersion objective on an Olympus BX50WI upright microscope equipped with a video camera system (COHU 4912).

Pipettes of typical resistance of 6-9 $\mathrm{m} \Omega$, made of borosilicate glass, were filled with an internal solution containing (in $\mathrm{mM}$ ) the following: K-gluconate, 135; $\mathrm{KCl}, 5 ; \mathrm{MgCl}_{2}, 2 ; \mathrm{CaCl}_{2}, 0.5$; HEPES, 5; EGTA, 5; ATP-Mg, 5 ; Tris-GTP, 0.5 ; adjusted to $\mathrm{pH}$ 7.3. In GDP- $\beta$ S experiments, Tris-GTP was replaced by GDP- $\beta$ S ( $1 \mathrm{~mm}$ ), a nonhydrolyzable analog of GDP (Eckstein et al., 1979), as previously described by Holz et al. (1986). Recordings of EPSCs in whole-cell patch-clamp using an Axopatch 200B amplifier (Molecular Devices) began after the current reached a steady state. The evoked EPSCs (eEPSCs) of lamina II neurons were induced by an electrical stimulation with a fixed intensity $(0.4 \mathrm{~ms}, \sim 0.4 \mathrm{~mA}$, and 0.2 $\mathrm{Hz}$ ) through a bipolar electrode $(\mathrm{Pt} / \mathrm{Ir})$ placed on the dorsal root entry zone.

Recordings were filtered at $2 \mathrm{kHz}$. Data were analyzed using pCLAMP10 (Molecular Devices) and GraphPad Prism (GraphPad) software. In all experiments, a single neuron per slice was recorded.

All data are expressed as the mean \pm SEM, and statistical significance was assessed with an unpaired Student's $t$ test, with $p<0.05$ (two-tailed) considered being significant. 


\section{Behavioral testing in mice}

Mice were acclimatized to handling and testing procedures twice a day for $3 \mathrm{~d}$ before behavioral testing.

Tail immersion test. The tail of the mice was immersed in a water bath maintained at $4,10,15,42,46,48$, and $50^{\circ} \mathrm{C}$. The latency time for tail withdrawal was determined and a cutoff time of $30 \mathrm{~s}$ was set to avoid injury.

Paw lift tests. Mechanical allodynia and hyperalgesia were assessed on mice using the von Frey hair filaments of three different bending forces ( $0.07 \mathrm{~g}$, corresponding to an innocuous stimulation, $0.6 \mathrm{~g}$ intermediate, and 1.4 g noxious). The filaments were pressed perpendicularly to the plantar surface of the hindpaw until they bent. For each filament, five stimuli were applied with an interval of 3-5 s. Data were analyzed by a two-way ANOVA and Dunnett's post hoc test, for time course studies. One-way ANOVA with a Newman-Keuls post hoc test was used to analyze the effect of the different treatments determined by the AUCs. The level of statistical significance was set at $p<0.05$.

Formalin test. After acclimatization for $20 \mathrm{~min}$ in the test chamber, mice received $20 \mu \mathrm{l}$ of $5 \%$ formalin injected subcutaneously into the plantar surface of the hindpaw. They were then placed in a Plexiglas box. Biting and licking of the injected paw were monitored, and the total duration of these actions in seconds was measured during the two peaks of the typical biphasic pain behavior. The spontaneous aversive response corresponding to the early phase was assessed during the first $10 \mathrm{~min}$. The second peak of aversive behavior was observed from 15 to 50 min after formalin administration. Data were analyzed by a two-way ANOVA and Bonferroni's post hoc test.

\section{Behavioral testing in rats}

Paw pressure test in rats. Rats were submitted to the paw pressure test previously described by Randall and Selitto (1957). Nociceptive thresholds, expressed in grams, were measured with an Ugo Basile analgesimeter (Apelex, tip diameter of the probe $1 \mathrm{~mm}$, weight $30 \mathrm{~g}$ ) by applying an increasing pressure to the right hindpaw of rats until a squeak (vocalization threshold) was obtained (cutoff was $750 \mathrm{~g}$, except for carrageenantreated animals for which the cutoff was $500 \mathrm{~g}$ ). Before treatments, rats were habituated to the test by handling without submitting them to paw pressure. Then, after having obtained two consecutive stable vocalization threshold values, treatment effects were assessed after 15, 30, 45, 60, 90, and $120 \mathrm{~min}$. The results are expressed as vocalization thresholds, in grams. To investigate global effects, areas under the time course curves (AUCs, g.min) of the antihyperalgesic effects were calculated from individual scores at each time, using the trapezoidal method. Data were analyzed by a two-way ANOVA followed by a Bonferroni's test, when the time course of the effects was studied. One-way ANOVA followed by a Student-Newman-Keuls' test was used to analyze the effect of the different treatments determined by the AUCs. The level of statistical significance was set at $p<0.05$.

\section{Inflammation or neuropathic pain models}

Carrageenan-induced inflammatory mechanical hyperalgesia. Thresholds to mechanically induced vocalization were assessed with animals presenting hyperalgesia elicited by a subcutaneous injection of $2 \%$ $\lambda$-carrageenan (200 $\mu \mathrm{l}$ for rat and $20 \mu \mathrm{l}$ for mice) into the right hindpaw.

Chronic constriction injury (CCI) model. Unilateral peripheral mononeuropathy was induced according to the method described by Bennett and Xie (1988). Briefly, after determining vocalization thresholds, rats were anesthetized with sodium pentobarbital $(50 \mathrm{mg} / \mathrm{kg}$ i.p. $)$ and four chromic gut (5-0) ligatures were tied loosely (with $\sim 1 \mathrm{~mm}$ spacing) around the right common sciatic nerve. The nerve was constricted to a barely discernible degree, so that circulation through the epineurial vasculature was not interrupted. Only animals presenting a decrease $\geq 15 \%$ of the presurgery value of vocalization threshold were selected.

\section{Experimental procedure}

For all experiments, unless stated otherwise, treatments were injected intrathecally. To avoid uncontrolled environmental influences, a block procedure was used whereby animals were tested in groups, with the number of animals in each group corresponding to the number of conditions of the experiment. Therefore, all the conditions were tested at once on the different individuals of the group in the same short lapse of time. For example, for an experiment with five different conditions (e.g., negative control, positive control, and three different doses of drug), each group contained five animals, each of which received one of the five treatments of the experiment. Treatments were randomized and performed blind. Experiments were performed in a quiet room where animal behaviors were observed by a single experimenter.

Intrathecal injections were performed under isoflurane anesthesia (4\% induction, 2\% maintenance), as previously described (Mestre et al., 1994). Briefly, the anesthetized animal was held in one hand by the pelvic girdle, and a 25 -gauge X1-inch needle connected to a $25 \mu$ l Hamilton syringe was inserted into the subarachnoid space between lumbar vertebrae L5 and L6, until a tail flick was elicited. The syringe was held in position for few seconds after the injection of a volume of $10 \mu \mathrm{l} / \mathrm{rat}$ and of $5 \mu \mathrm{l} /$ mouse.

\section{Knockdown of spinal $m$ Glu4 receptor expression by antisense oligonucleotides}

An antisense (AS) oligonucleotide was designed based on rat mGlu4 sequences (GenBank gene ID: 24417) in regions lacking known splice variants (AS: TAAAGGCTGAGGAGTAGG). A scramble oligonucleotide control was used (scrambled control: GCCTGCTAGAATGCCATT). The absence of complementarity of the scrambled control to any registered nucleotide sequences was verified by a blast search in the GenBank. They were synthesized by Eurofins MWG Operon.

The oligonucleotides were reconstituted in saline before administration. Intrathecal injection of oligonucleotides (AS/scrambled control, $12.5 \mu \mathrm{g}$ ) or saline was performed using a volume of $10 \mu \mathrm{l}$ via direct transcutaneous injection between the dorsal aspects of L5 and L6 under slight anesthesia with volatile isoflurane (3.5\%). This treatment was repeated twice daily for $4 \mathrm{~d}$. The studies were performed in naive, inflamed, and mononeuropathic rats. Pain scores were determined before oligonucleotide treatments and then on day 4 . In each experiment, 6-10 animals per group were used.

\section{Sample collection}

Four days after intrathecal injections of AS or mismatch (MM) oligonucleotide, the spinal cords were collected from CCI and carrageenantreated rats $(n=4$ for each group). Animals were first deeply anesthetized, and the L4-L6 spinal cord segments were then extracted and immediately placed on ice-cooled glass dish. The spinal cords were further subdivided into dorsal and ventral halves by cutting straight across from the central canal laterally to a midpoint in the white matter.

\section{Western blot}

The ipsilateral and contralateral of each CCI or carrageenan-treated rat spinal cord were separated and subsequently processed for Western blot analysis. The L4-L6 ipsilateral and contralateral spinal cord dorsal segments were homogenized in lysis buffer containing $50 \mathrm{~mm}$ HEPES, $\mathrm{pH}$ 7.5, 1\% Triton X-100, 10 mм EDTA, $150 \mathrm{~mm} \mathrm{NaCl}, 10 \mathrm{~mm} \mathrm{Na}_{4} \mathrm{P}_{2} \mathrm{O}_{7}, 0.1$ $\mathrm{M} \mathrm{NaF}, 2 \mathrm{~mm}$ vanadate, $100 \mathrm{U} / \mathrm{ml}$ aprotinin, $20 \mu \mathrm{M}$ leupeptin, and $0.5 \mathrm{~mm}$ PMSF. The total amount of protein in each sample was determined using the BCA Protein Assay Kit (Pierce-Thermo Scientific) before loading on polyacrylamide gels. Spinal cord homogenates ( $80 \mu$ g protein) were separated using 7.5\% SDS-PAGE and transferred to nitrocellulose. After the blots had been washed with TBST (10 mm Tris-HCl, pH 7.6, $150 \mathrm{~mm}$ $\mathrm{NaCl}, 0.05 \%$ Tween-20), the membranes were blocked with $5 \%$ skim milk for $1.5 \mathrm{~h}$ and incubated at $4^{\circ} \mathrm{C}$ overnight with a primary antibody specific for $\beta$-actin (1:5000, loading control, Sigma) and mGlu4 $(1 \mu \mathrm{g} /$ $\mathrm{ml}$, catalog \#51-3100, Invitrogen). After washing with TBST, membranes were incubated for $1 \mathrm{~h}$ with HRP-conjugated anti-rabbit IgG or antimouse IgG secondary antibody (1:10,000, Pierce-Thermo Scientific) to detect mGlu4 or $\beta$-actin, respectively. The bands were visualized with SuperSignal WestPico chemioluminescent substrate (Pierce-Thermo Scientific). The positive pixel area of specific bands was measured with a computer-assisted image analysis system (ChemiDoc XRS, Bio-Rad) and normalized against the corresponding $\beta$-actin loading control bands. The ratio of knockdown of spinal mGlu4 expression by AS oligonucleotide was calculated. The mean value of ipsilateral and contralateral spinal mGlu4 expression in animals treated by MM oligonucleotide was set 
at $100 \%$. Thus, the percentage change in the mGlu4 expression in each sample was calculated.

\section{RNA expression}

Extraction. Total RNAs were prepared from pooled DRG (L4-L6) using the TRIzol method according to the manufacturer's instructions (Invitrogen). Reverse transcriptions were performed using $1 \mu \mathrm{g}$ of total RNA with random primers and $\mathrm{M}-\mathrm{MuLV}$ reverse transcriptase (New England Biolabs).

$q P C R$. The expression levels of genes were determined by qPCR using SYBR Green and a Roche LightCycler 480. Primer pairs were validated using DNA plasmid of the gene of interest as a template. Experiments were performed on $2 \mathrm{ng}$ of the cDNA product using $1 \times$ SYBR Green PCR Master (Roche) and 300 nм concentration of each primer pair.

Data were analyzed using the threshold cycle $\left(C_{t}\right)$ relative quantification method. Three housekeeping genes (HKGs) among the eight tested were chosen to normalize the results using the geNorm software. The expression level of each gene was normalized according to the formula

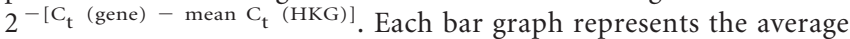
gene expression levels measured in DRG from at least three animals each being tested in three independent qPCR experiments.

qPCR data were analyzed with unpaired Student's $t$ test. Data are expressed as mean \pm SEM, and the levels of significance were set at $p<$ $0.05, p<0.01$, and $p<0.001$.

Drugs

ACPT-I was purchased from Tocris Bioscience, L-AP4, $\omega$-conotoxin GVIA, $\omega$-agatoxin IVA, NBQX, and Tertiapin Q from Abcam Biochemicals. LSP4-2022 was synthesized in the laboratory of F.A. following a procedure analogous to that previously described (Selvam et al., 2010; Acher et al., 2012). All solutions were prepared just before experiments.

\section{Results}

mGlu4 receptors are localized in the lamina II of the mice spinal cord both in the terminals of unmyelinated afferents and spinal neurons

The superficial laminae of the dorsal horn of the spinal cord represent the area of the CNS where the first modulation of painrelated information occurs. This region receives sensory information from primary afferents responding to noxious and non-noxious stimuli. This incoming information is then processed by interneurons, important for maintaining normal sensory function, and then transmitted to projection neurons for relay to the brain (Basbaum et al., 2009; Todd, 2010).

Previous immunocytochemistry studies revealed the presence of mGlu4 receptors in presynaptic elements from afferent fibers in lamina II of the dorsal horn in the rat spinal cord (Azkue et al., 2001). However, the nature of the neurons expressing this receptor was not determined. We therefore performed immunofluorescence staining in mice spinal cord slices and DRG with an mGlu4 antibody and various markers of neurons involved in pain transmission.

Immunoreactivity was absent in mGlu4KO mice both in immunofluorescence (Fig. 1A) and in Western blot experiments (Fig. $1 B$ ), ruling out nonspecific labeling of the mGlu4 antibody. Although the presence of mRNA encoding mGlu4 receptor has previously been detected by in situ hybridization in neurons with small- and medium-size bodies in the DRG (Ohishi et al., 1995a), we could not detect mGlu4 receptor immunostaining in DRGs, suggesting that their expression level in these neuronal cell bodies is under the detection limit.

We observed that mGlu4 receptors are expressed mostly in the inner lamina II of the dorsal horn of the spinal cord in mice (Fig. 2). In this lamina, we detected mGlu4 immunoreactivity in C-tactile low threshold mechanical receptive (C-LTMR) afferents expressing the vesicular glutamate transporter 3 (VGLUT3). Of note, these C-LTMR neurons convey non-noxious touch sensations in healthy conditions (Löken et al., 2009; Li et al., 2011) and are involved in mechanical hypersensitivity associated with chronic pain (Seal et al., 2009). A small proportion of mGlu4 receptor staining $(<10 \%)$ merged with peptidergic and nonpeptidergic $\mathrm{C}$ fibers markers, such as substance $\mathrm{P}(\mathrm{SP})$, calcitonin gene-related peptide (CGRP), or isolectin B4 (IB4), respectively. The labeling of mGlu4 receptors also partially overlaps with staining of protein kinase $\mathrm{C} \gamma(\mathrm{PKC} \gamma)$ interneurons in inner lamina II (Fig. 2). PKC $\gamma$-expressing interneurons are excitatory neurons, which play an important role in the processing of tactile inputs both in physiological and pathological conditions and are notably thought to mediate injury-induced hypersensitivity (Malmberg et al., 1997; Polgár et al., 1999; Miraucourt et al., 2007; Neumann et al., 2008; Lu et al., 2013). By contrast, mGlu4 receptor labeling does not significantly overlap with NF200 $(<1 \%)$, a marker of myelinated $\mathrm{A} \beta$ or $\mathrm{A} \delta$ fibers. In accordance with previous electronic microscopy data indicating that mGlu4 is commonly observed in presynaptic terminals in the dorsal spinal cord (Azkue et al., 2001), most mGlu4 receptor immunoreactivity merges with that of synaptophysin, a membrane glycoprotein characteristic of presynaptic vesicles (Wiedenmann and Franke, 1985), and bassoon, a protein expressed at the presynaptic nerve terminals (tom Dieck et al., 1998).

To further examine the nature of neurons expressing mGlu4 receptors, we performed a unilateral dorsal rhizotomy of the fourth lumbar cord segment on mice. Fifteen days after the rhizotomy, we performed a triple immunostaining of mGlu4, VGLUT3, and IB4 on cervical to lumbar spinal cord slices (Fig. 3). As expected, both IB4 and VGLUT3 labeling in superficial layers of the dorsal horn of the fourth lumbar cord segment was markedly reduced $(>70 \%)$ on the ipsilateral, but not the contralateral, side to the dorsal rhizotomy. On the other hand, 

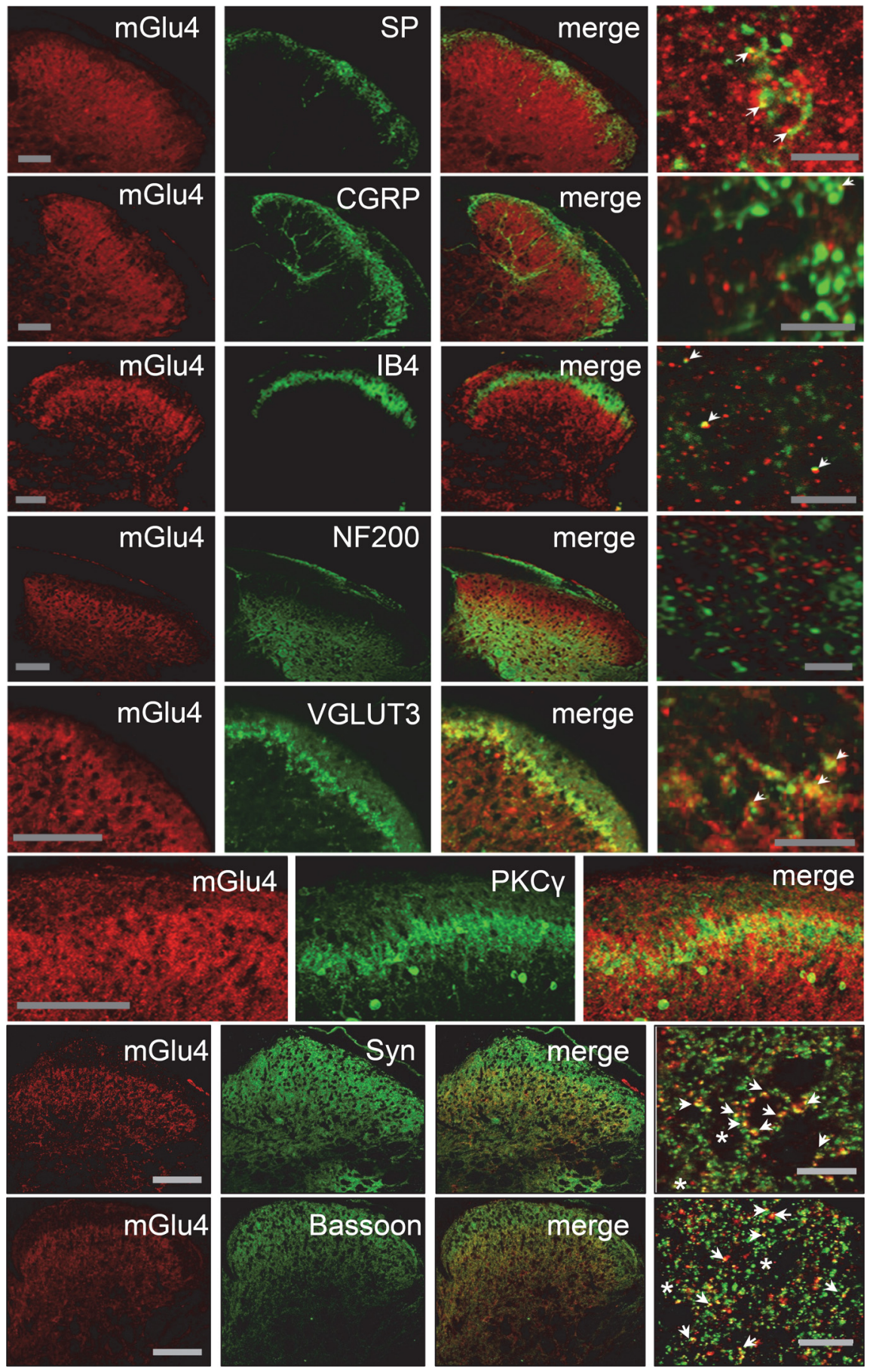

Figure 2. Localization of mGlu4 receptors in inner lamina II of the dorsal horn of mice spinal cord. Double immunolabeling of


antibodies against main markers of the different sensory fibers or interneurons (green), and markers of presynaptic element (green). Immunoreactivity of mGlu4 receptors is detected in the inner lamina Il of dorsal horn. The $\mathrm{mGlu} 4 \mathrm{staining}$ is mostly, but not exclusively, colocalized with VGLUT3 and overlaps to a large extent with interneurons that express PKC $\gamma$ (green). Of note, because mGlu4 and PKC $\gamma$ primary antibodies originate from the same species (rabbit), the two labeling were performed in consecutive adjacent slices. A small proportion of mGlu4 receptor staining merges with SP, CGRP, or IB4 (green) staining (arrows), whereas no mGlu4 receptor staining merges with NF200 (green). Labeling of mGlu4 and the presynaptic proteins synaptophysin and bassoon merges to a large extent (arrows), but not exclusively (asterisks). Scale bars: three left columns, $100 \mu \mathrm{m}$; right column corresponds to a section of the third column at higher magnification. Scale bars, $10 \mu \mathrm{m}$.

mGlu4 imnuoreactivity was only partially reduced after rhizotomy on the ipsilateral side $(<25 \%, n=4$ independent experiments), suggesting both a peripheral and spinal origin of these processes.
The localization of mGlu4 receptors in superficial layers of the dorsal horn of the spinal cord, both in the terminals of unmyelinated C-fibers and in spinal interneurons, provides neuroanatomical clues of the putative involvement of this receptor in the modulation of pain.

\section{Presynaptic mGlu4 receptors reduce} glutamatergic neurotransmission through inhibition of $\mathrm{Ca}_{\mathrm{v}} 2.2$ channels in spinal cord slices

We then studied the role of mGlu4 receptors on glutamatergic neurotransmission in lamina II dorsal horn neurons. Using the patch-clamp technique, we measured eEPSCs on lamina II neurons from lumbar (L4-L6) spinal cord slices of 2- to 3-week-old mice.

Having confirmed that in young animals, as in adult mice, mGlu4 receptor immunostaining could be observed in lamina II (Fig. 4A), we then compared the effects of two ligands: LSP4-2022, a recently identified mGlu4 selective agonist, and L-AP4, a nonselective Group III mGluRs agonist. LSP4-2022 is 100 and 500 times more potent at mGlu4 than at mGlu7 and mGlu8, respectively (Goudet et al., 2012). Both ligands significantly decreased the amplitude of eEPSCs (Fig. 4B,C). Interestingly, application of $5 \mu \mathrm{M}$ LSP4-2022 or $50 \mu \mathrm{M} \mathrm{L}-\mathrm{AP} 4$ yielded to a similar inhibition of eEPSC amplitude by $43.9 \pm 3.9 \%(n=10)$ and $47.4 \pm$ $4.4 \%(n=9)$, respectively (Fig. $4 C)$. At the concentrations used, in addition to activating mGlu4, L-AP4 will also activate mGlu8, whereas LSP4-2022 will not, suggesting that most, if not all, of the effects are mediated by mGlu4 receptor activation. The full blockade of the eEPSCs by addition of 50 $\mu \mathrm{M}$ NBQX, an iGluR (AMPA receptors) antagonist, at the end of the experiment, proved their glutamatergic nature.

In the next experiment, we replaced GTP by GDP- $\beta S$, a stable GDP analog that blocks G-protein-mediated responses, in the patch pipette. Into the recorded neuron, GDP- $\beta S$ competes with GTP on G-proteins, thereby blocking GTP-dependent activation of the G-proteins by hormones and neurotransmitters (Holz et al., 1986). This method has been proven to efficiently block postsynaptic G-protein-mediated modulation of glutamatergic transmission in various CNS synapses, including spinal cord (e.g., Rebola et al., 2008; Yang et al., 2011; Fan et al., 2013). However, in our experiments, the inhibition of eEPSC amplitude by LSP4-2022 is not modified, suggesting that the effect of the drug on transmission occurs through presynaptic receptors (Fig. $4 D$ ), in accordance with immunofluorescence data showing colocalization of mGlu4 with presynaptic markers (Fig. 2). 
Using specific ion channel blockers, we then demonstrated that the modulation of spinal glutamatergic transmission by mGlu4 receptor required Cav2.2, but not Cav2.1 or GIRK channels. Indeed, neither Cav2.1 blockade by $\omega$-agatoxin IVA $(\omega$ Agtx, 100 nM) nor GIRK blockade by tertiapin Q $(200 \mu \mathrm{M})$ altered the amplitude of eEPSCs inhibition by $50 \mu \mathrm{M}$ LSP4-2022, whereas Cav2.2 blockade by $\omega$-conotoxin GIVA $(\omega$-Cgtx, $1 \mu \mathrm{M})$ almost completely abolished the effect of LSP4-2022 (Fig. 5). Cav2.2 is known to be mostly expressed in presynaptic terminals of $\mathrm{C}$ - and $\mathrm{A} \delta$-fibers (Heinke et al., 2004), further supporting the presynaptic localization of mGlu4 receptors and an involvement in the regulation of nociceptive transmission.

Because neurotransmission is known to be modulated in the spinal cord under conditions of chronic pain, we compared the depressant effect of mGlu4 receptor activation on transmission in spinal cord slices from naive and inflamed mice. Twenty-four hours before dissection, inflammation was induced by bilateral injection of a solution of CFA in the hindpaws of young mice. Interestingly, the inhibition of eEPSC amplitude by 5 or 50 $\mu \mathrm{M}$ LSP4-2022 was increased in spinal cord slices from inflamed compared with naive animals (Fig. 6). Indeed, whereas $50 \mu \mathrm{M}$ LSP4-2022 depressed the eEPSC amplitude by $53.1 \pm 4.7 \%$ in control conditions, this depressant effect is significantly raised to $67.6 \pm 1.5 \%$ in inflammatory conditions. This indicates that the inhibition of glutamatergic neurotransmission by mGlu4 receptor is reinforced in the spinal cord of inflamed mice.

\section{Physiological and pathophysiological role of mGlu4 receptors} in nociception and inflammatory pain in mice

After showing that mGlu4 receptors are present in lamina II and modulate the neurotransmission, we evaluated the physiological consequences of the genetic deletion of mGlu4 receptors in mice on thermal, mechanical, or chemical sensitivity.

Sensitivity to cold or heat measured by the tail immersion test at temperatures ranging from $4^{\circ} \mathrm{C}$ to $50^{\circ} \mathrm{C}$ did not differ between mGlu4 knock-out (KO) mice and wild-type (WT) littermates (Fig. 7A). Similarly, mechanical perception in response to punctate innocuous, intermediate, and noxious stimuli elicited by von Frey filaments of different strength $(0.07,0.6$, and $1.4 \mathrm{~g}$, respectively) was not altered in mGlu4KO mice (Fig. $7 D$ ), although we noticed a significantly higher threshold for tail withdrawal in response to noxious mechanical compression using the Randall \& Sellitto apparatus (Fig. 7B)

In the formalin test, we observed a weak but significant increase of nociceptive behavior of mGlu4KO compared with WT mice during the second phase (Fig. 7C) but not in the first phase. This increase seems to be the result of a faster development of the inflammatory phase of the response to formalin injection, as can be seen by its kinetics. We further investigated the possible involvement of mGlu4 receptors in pathological inflammatory conditions using the usual model of carrageenan-induced inflammatory pain and mechanical stimuli. Four hours after induction of inflammation by an injection of carrageenan solution, a comparable mechanical hypersensitivity was observed in inflamed mGlu4KO and their WT littermates (Fig. 7D). These data suggest that the lack of mGlu4 receptors does not affect the inflammatory hypersensitivity once established.

\section{Exogenous activation of spinal mGlu4 receptors reduced} inflammatory and neuropathic mechanical hypersensitivity We then examined whether exogenous pharmacological activation of spinal mGlu4 receptors was able to reduce mechanical hypersensitivity induced by inflammation or neuropathy.

We first evaluated the effect of spinal mGlu4 receptors activation using von Frey filaments eliciting innocuous to noxious mechanical stimuli in a carrageenan-induced model of inflammation in C57BL/ 6 mice. As can be seen in Figure 8, activation of spinal mGlu4 receptors by intrathecal injection (i.t.) of LSP4-2022 dose-dependently reduced mechanical hypersensitivity.

We verified that the mGlu4 receptor-induced correction of mechanical hypersensitivity remained true across species because terminals of afferent fibers have been shown to exhibit differential segregation in $\mathrm{PKC} \gamma$-positive layer in spinal cord of rodents (Neumann et al., 2008). We tested the effect of spinal mGlu4 receptor activation in naive "healthy" rats and in models of inflammation and neuropathic pain using the paw pressure test (Randall and Selitto, 1957).

In inflamed or neuropathic rats, mechanical sensitivity was assessed by measuring the vocalization threshold to paw pressure on right hindpaw. Inflammation was induced by injection of carrageenan in the rat hindpaw and mononeuropathy by CCI of the sciatic nerve. As previously shown in healthy rats with ACPT-I, a Group III mGluR agonist (Goudet et al., 2008), administration of LSP4-2022 (5, 10, or $15 \mu \mathrm{g} / \mathrm{rat}$, i.t.) failed to induce antinociception, in contrast to morphine $(10 \mu \mathrm{g} / \mathrm{rat}$, i.t. $)$ that significantly increased the vocalization threshold after mechanical stimulation 
A
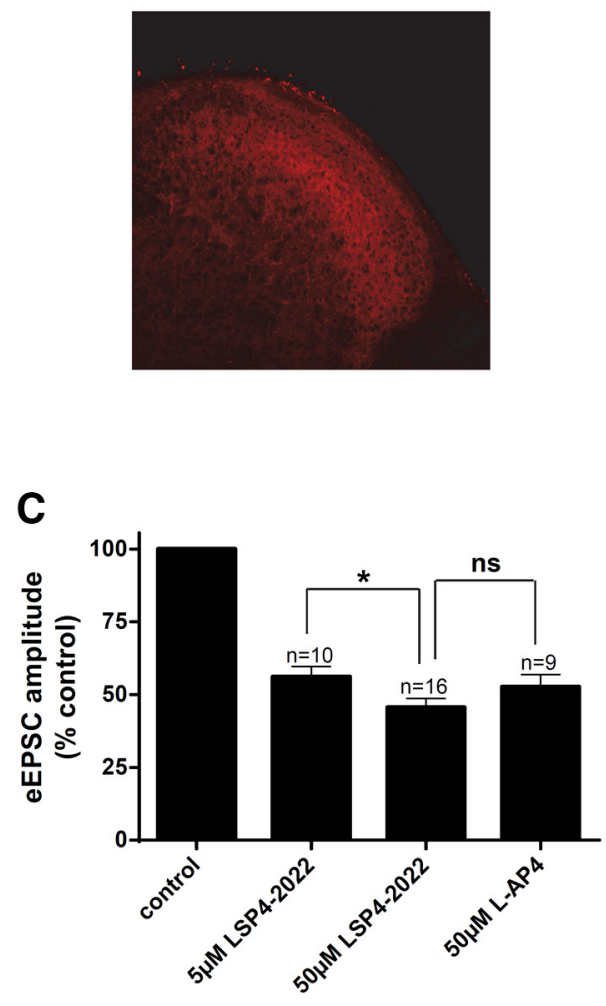

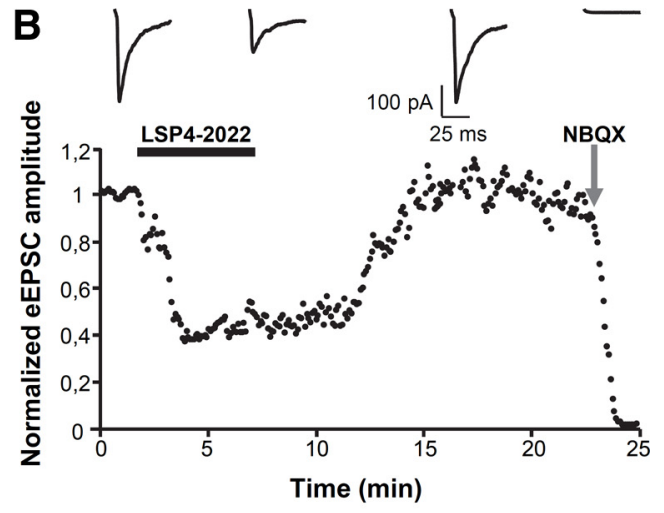

D

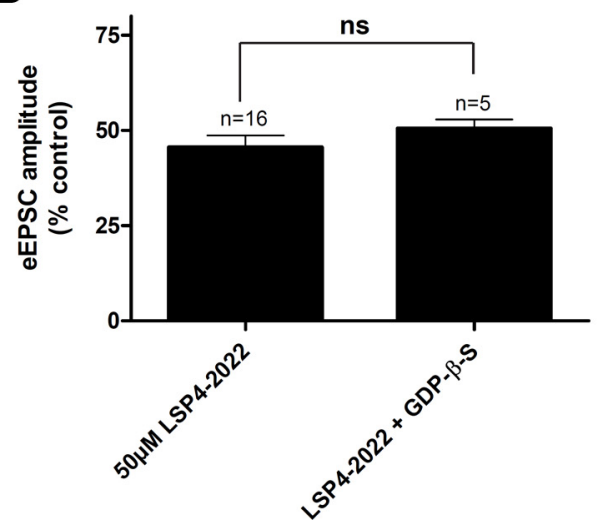

Figure 4. Activation of mGlu4 strongly reduces excitatory neurotransmission in spinal cord slices. Electrophysiological recording of eEPSCs in lamina II neurons from spinal cord slices of 2- to 3-week-old mice were performed using the whole-cell patch-clamp technique. Postsynaptic currents were evoked by an electrical stimulation using a bipolar electrode placed on the dorsal root entry zone. $\boldsymbol{A}$, Immunofluorescence staining of mGlu4 receptors in lamina II of dorsal horn of spinal cord section from young mice. $\boldsymbol{B}$, Time course of eEPSC amplitude before and after bath application of $50 \mu \mathrm{m}$ LSP4-2022, followed by a wash out and application of $50 \mu \mathrm{m}$ NBQX. The amplitude of eEPSCS was normalized to amplitude before drug application. Top, Sample current traces recorded in these conditions. C, Histogram of mean \pm SEM of eEPSC amplitude in the absence and in the presence of 5 or $50 \mu \mathrm{m}$ of LSP4 -2022 or in the presence of $50 \mu \mathrm{mL}-\mathrm{AP4}$, expressed as the percentage of amplitude in control conditions, before drug application. $D$, Histogram of mean \pm SEM of eEPSC amplitude in the presence of $50 \mu \mathrm{m}$ of LSP4-2022 with or without GDP- $\beta S$, a stable GDP analog that blocks $\mathrm{G}$-protein-mediated signaling in the recorded neuron, in the patch pipette. ${ }^{*} p<0.05$. ns, Not significant.

(Fig. 9A). However, both in the rat model of carrageenaninduced inflammatory pain (Fig. $9 B$ ) and in mononeuropathic rats (CCI model) (Fig. 9C), intrathecal injection of LSP4-2022 (1-20 $\mu \mathrm{g} / \mathrm{rat}$ ) dose-dependently inhibited mechanical hyperalgesia. Maximal increase of the vocalization threshold was observed 45 min after the injection of LSP4-2022 and corresponded to a complete reversal of hyperalgesia.

Together, these results illustrate that pharmacological activation of spinal mGlu4 receptors abolishes mechanical hyperalgesia associated with both inflammation and nerve injury but does not affect reaction to noxious mechanical stimulus in healthy rats.

\section{Demonstration of the mGlu4 receptor involvement in the antihyperalgesic effect of LSP4-2022}

A genetic approach was used to obtain specific inactivation of mGlu4 receptors by testing the impact of both knock-out and a knockdown strategies on the involvement of mGlu4 receptors in the effects of the agonist.

We first evaluated the consequences of the genetic deletion of mGlu4 receptors in mice on the ability of LSP4-2022 to alleviate inflammatory mechanical hypersensitivity (Fig. 10A). Using the model of carrageenan-induced inflammatory pain and von Frey stimuli, we compared the effect of the maximal dose of LSP4$2022(10 \mu \mathrm{g} /$ mice, i.t. $)$ on mGlu4KO mice and their WT littermates. The ability of LSP4-2022 to reduce carrageenan-induced hypersensitivity in response to applied stimuli is significantly reduced in the mGlu4 KO mice compared with their WT littermates (Fig. 10A). The effect of LSP4-2022 on sensitivity to noxious mechanical stimulation is reduced by $78 \%$ in mice lacking mGlu4, compared with their WT littermates. The reduced effect of LSP4-2022 in mGlu4KO mice reveals the major role of mGlu4 receptors in the observed effects. However, there is still a slight but significant remaining effect of LSP4-2022 in mGlu4 $\mathrm{KO}$ mice. This suggests that, at this dose, other Group III subtypes may be also involved in this response, albeit to a much lesser extent.

Using a knockdown strategy in rats, we further examined the role of spinal mGlu4 receptors in hyperalgesia. The aim of this approach was as follows: (1) to compare the consequences of a local and transient silencing of mGlu4 to the results obtained with the constitutive knock-out of mGlu4 in mice; and (2) to specifically block the mGlu4 mediated response in the absence of selective antagonists. Silencing of spinal mGlu4 was achieved using AS oligonucleotides injected intrathecally according to the method described by Mestre et al. (1994). This method allows the AS oligonucleotides to reach the DRG neurons (Bourinet et al., 2005). Rats were treated by vehicle, scrambled control oligonucelotides (MM), or mGlu4 receptor targeting AS oligonucleotides (AS) injected intrathecally twice daily for $4 \mathrm{~d}$. On the fourth day, mechanical sensitivity was assessed by the paw pressure test be- 

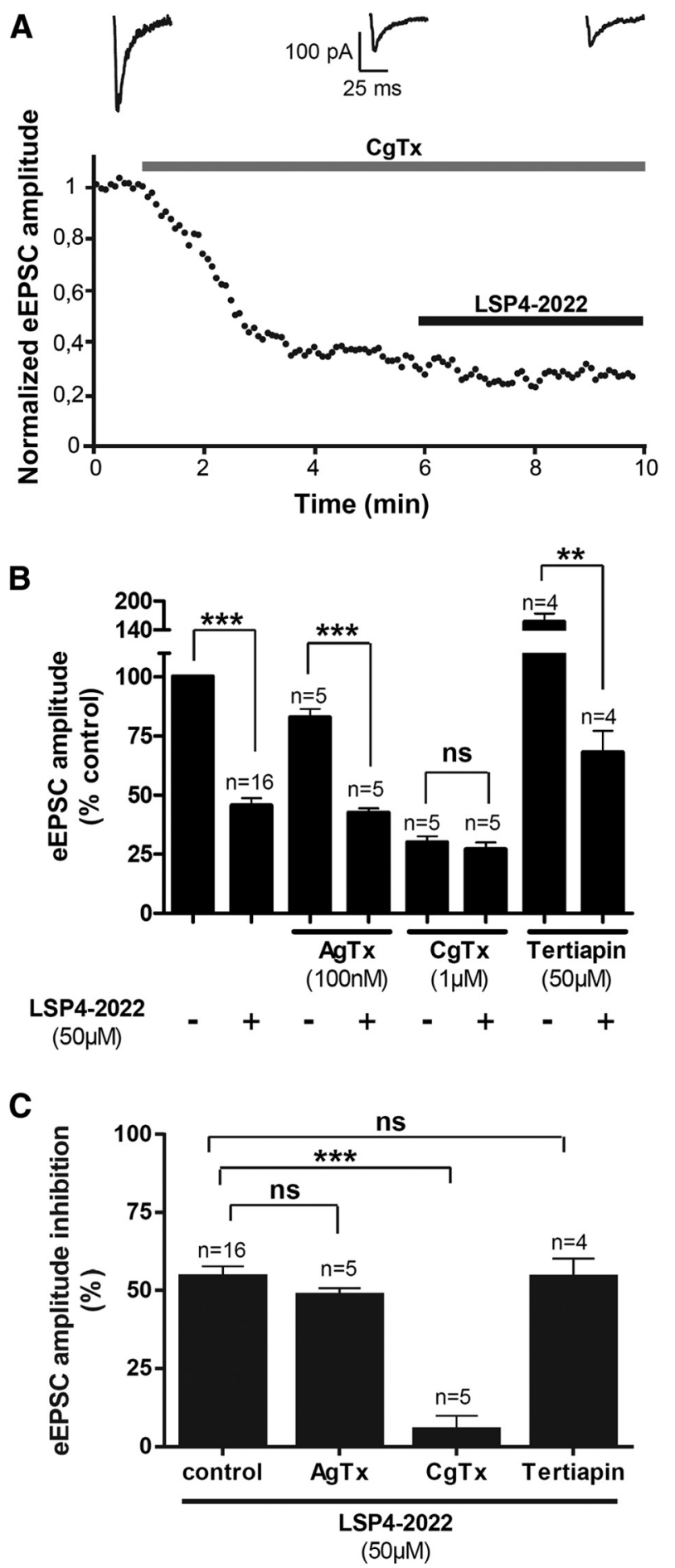

Figure 5. mGlu4 receptors regulates excitatory transmission through coupling to Cav2.2 channels. Evoked EPSCs were recorded in lamina II neurons from spinal cord slices of 2-to 3-week-old mice using the whole-cell patch-clamp technique. $A$, Bottom, Time course of eEPSC amplitude before and after bath application of $\omega$-Cgtx, a selective blocker of Cav2.2 channels, and $50 \mu \mathrm{m}$ LSP4-2022, an mGlu4 agonist. The amplitude of eEPSCs is normalized to amplitude before drug application. Top, Sample current traces recorded before drug application, after $\omega$-Cgtx, and in the presence of $\omega$-Cgtx and LPP4-2022. B, Histogram of mean \pm SEM of eEPSC amplitude in the absenceand in the presence of LSP4-2022 and different channel blockers: $\omega$-Cgtx, a selective blocker of Cav2.2 channels; $\omega$-Agtx, a selective blocker of Cav2.1 channels; and tertiapin $Q$, a selective blocker of GIRK channels. Current amplitudes are expressed as the percentage of amplitude before drug application. $C$, Histogram of mean \pm SEM of inhibition of eEPSC amplitude in the presence of the different channel blockers. Current amplitudes are expressed as the percentage of inhibition of the amplitude before LSP4-2022 application. ${ }^{* *} p<0.01 .{ }^{* * *} p<0.001$. ns, Not significant.
A

LSP4-2022

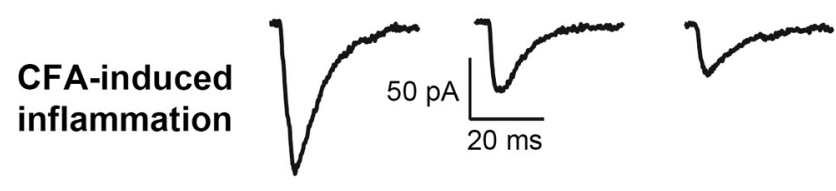

B

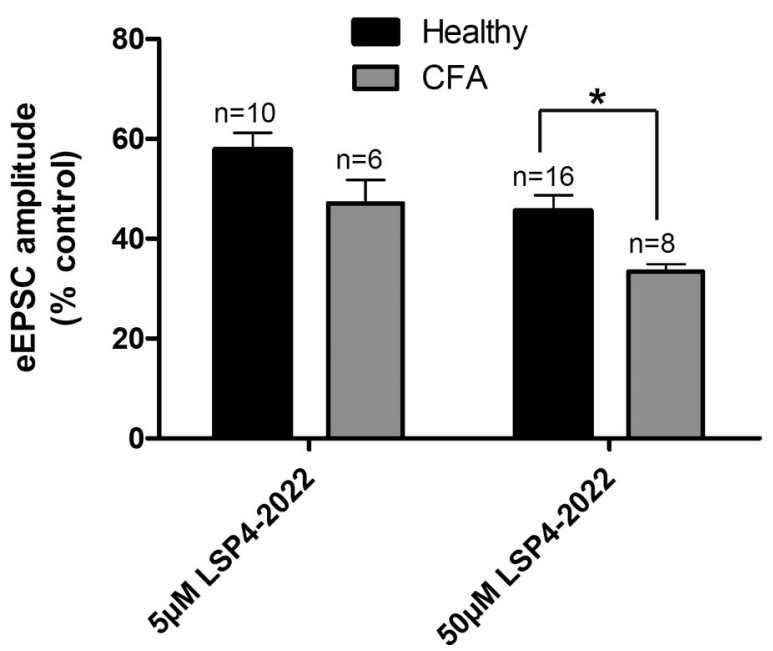

Figure 6. Inhibition of spinal excitatory neurotransmission by mGlu4 receptor is reinforced in inflammation. Electrophysiological recording of current eEPSCs in lamina II neurons from spinal cord slices of naive or inflamed young mice. Inflammation was induced by administration of CFA solution in hindpaws. Spinal cords were removed and recordings performed $24 \mathrm{~h}$ after

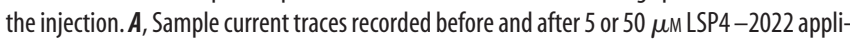
cation in naive or CFA-treated mice. $\boldsymbol{B}$, Histogram of mean \pm SEM eEPSC amplitude after application of 5 or $50 \mu \mathrm{m}$ LSP4-2022 in naive or inflamed mice, expressed as percentage of current amplitude before drug application. ${ }^{*} p<0.05$.

fore killing the animals and quantifying the degree of knockdown. Expression of mGlu4 mRNA in lumbar DRG extracts was significantly decreased by $38 \%$ after chronic treatment with AS, whereas expression in animals treated with MM was not altered (Fig. 10B). The protein level of mGlu4 in lumbar spinal cord extracts of animals treated by AS was decreased by $58 \%$ compared with animals treated by MM (Fig. 10C).

In the carrageenan-induced inflammation model, the effect of LSP4-2022 was significantly reduced (-54\%) in animals treated with AS oligonucleotides (Fig. 10D). Similarly, in mononeuropathic rats, this AS strategy significantly reduced the amplitude of antihyperalgesia induced by LSP4-2022 (-77\%), whereas this effect was unchanged in animals treated with MM (Fig. 10E). These results clearly confirm the antihyperalgesic role of the activation of spinal mGlu4 receptors both in inflammatory and neuropathic pain models and the potential therapeutic interest of mGlu4 receptor agonists.

Consistent with data obtained from the mGlu4KO mice, the lack of variation in vocalization thresholds after repeated treat- 


\section{A}

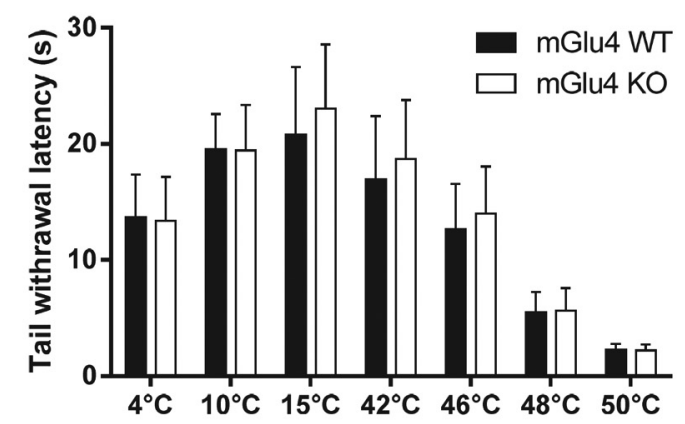

C

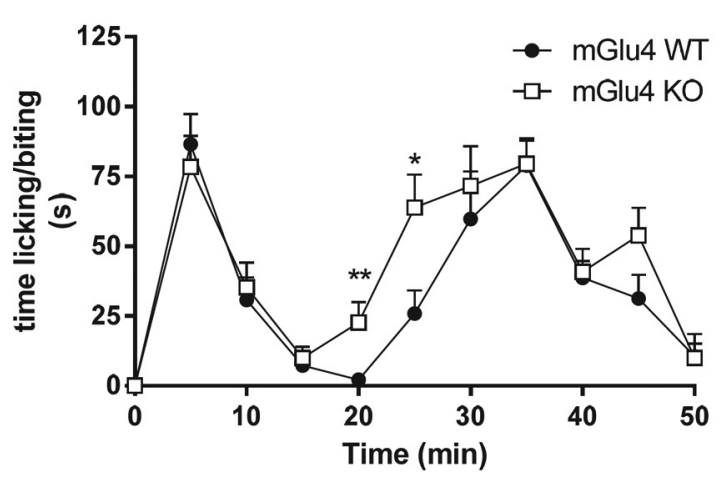

D Von Frey

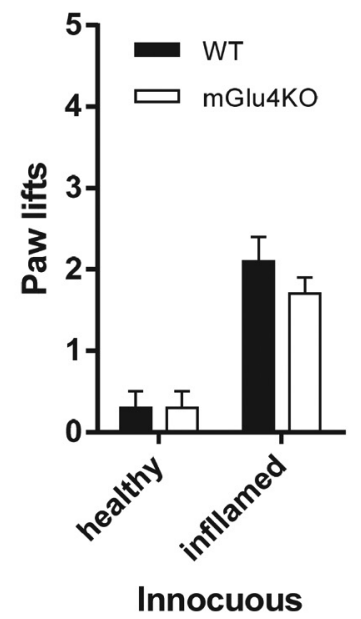

Tail immersion

Formalin

$$
\rightarrow \text { mGlu4 KO }
$$

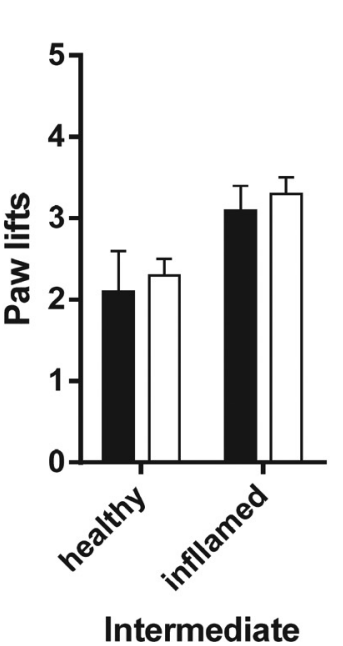

B

RS tail
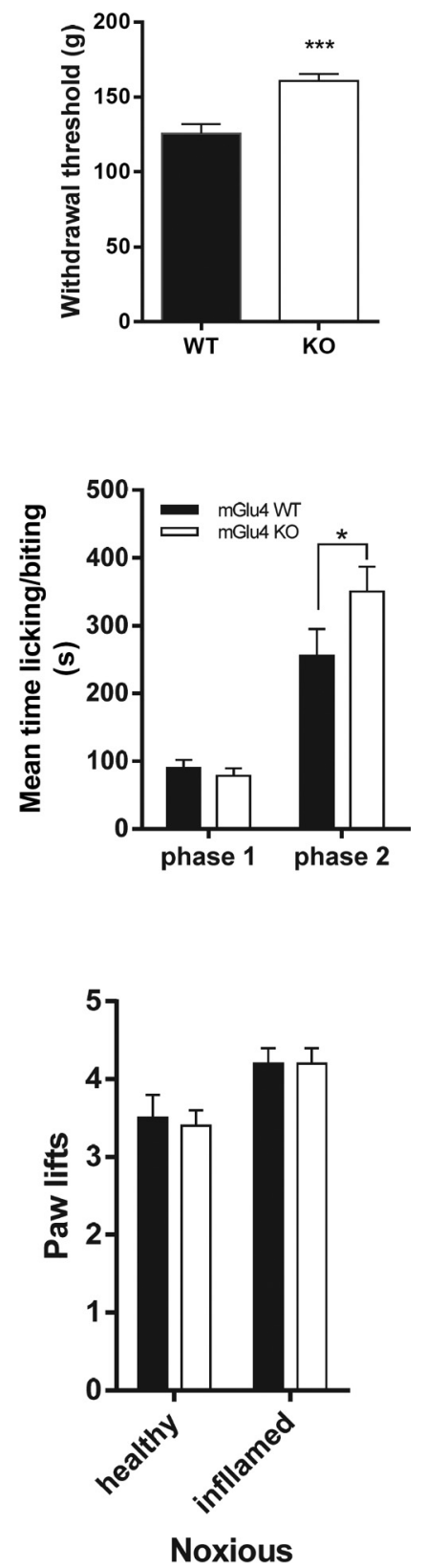

Figure 7. Perception of thermal, mechanical, and chemical stimuli in naive mGlu4KO mice. $\boldsymbol{A}$, mGlu4KO mice and their WT littermates display a similar thermal sensitivity, determined by measuring the latency to withdraw the tail immersed in water at temperatures ranging from $4^{\circ} \mathrm{C}$ to $50^{\circ} \mathrm{C}(n=10$ animals per group). $\boldsymbol{B}$, mGlu4KO mice display a significantly higher threshold for tail withdrawal after noxious mechanical stimuli evoked by tail compression in the Randall-Selitto (RS) than WT mice ( $n=10$ animals per group). C, Both mGlu4KO and WT mice displayed the typical biphasic time course of nocifensive behavior (paw licking/biting) after injection of $15 \mu$ l of a $5 \%$ formalin solution in the right hindpaw. The second phase of the response occurs faster for mGlu4K0 mice. Right, Histogram representing the mean time \pm SEM of nocifensive behavior during the first phase $(0-10 \mathrm{~min})$ and the second phase $(15-50 \mathrm{~min})$ of the formalin test. The response in the second phase is significantly higher for $\mathrm{mGlu} 4 \mathrm{KO}$ mice than for WT mice ( $n=8$ animals per group). $D$, Mechanical sensitivity assessed by measuring the number of paw lifts of five stimulations using von Frey filaments corresponding to innocuous ( $0.07 \mathrm{~g}$ ), intermediate $(0.6$ $\mathrm{g}$ ), and noxious $(1.4 \mathrm{~g})$ bending forces does not differ between mGlu4K0 and WT mice $\left(n=10\right.$ animals per group). ${ }^{*} p<0.05$. ${ }^{* *} p<0.01$. ${ }^{* * *} p<0.001$.

ment with AS compared with saline- or MM-treated groups suggests that, once established, the mechanical hypersensitivity is not affected by mGlu4 receptor silencing.

Systemic administration of an mGlu4 receptor agonist alleviates pain hypersensitivity in inflammation

The ability of spinal mGlu4 receptors to abolish the mechanical hypersensitivity caused either by inflammation or nerve injury highlights the therapeutic potential of these receptors for the development of novel analgesics. However, the question of whether a reduction of pain can be observed after a systemic administration of an mGlu4 receptor agonist remained unanswered. To address this point, we injected LSP42022 intraperitoneally $(1-30 \mathrm{mg} / \mathrm{kg})$ in rats subjected to carrageenan-induced inflammation. This particular ligand was chosen because of its ability to cross the blood-brain barrier, which has previously been documented in an animal model of Parkinson disease (Goudet et al., 2012). 
The acute intraperitoneal injection of LSP $4-2022(1-30 \mathrm{mg} / \mathrm{kg})$ in inflamed rats led to a significant and dose-dependent reduction of mechanical hyperalgesia measured using the paw pressure test (Fig. 11). The time course of LSP4-2022 antihyperalgesic effect was similar to that of morphine $(6 \mathrm{mg} / \mathrm{kg}$, i.p.), with a peak effect 30 min after administration, but the maximal efficacy of $30 \mathrm{mg} / \mathrm{kg}$ LSP4-2022 was $40 \%$ lower than that of morphine.

This result further highlights the interest of targeting mGlu4 receptors to alleviate painful hypersensitivity in an inflammatory context using LSP4-2022, and possibly other activators of mGlu4 receptors able to cross the blood-brain barrier.

\section{Discussion}

Because of current limitations in the therapeutic arsenal for pain management, there is a crucial need for the identification and development of alternative targets and strategies for the treatment of chronic pain. Targeting the modulatory role of mGluRs to prevent the glutamatergic overactivity associated with central sensitization of the pain neuraxis may be one of the hitherto unappreciated modalities to reduce chronic pain. In the present study, we present neuroanatomical, electrophysiological, pathophysiological, and pharmacological data that, together, highlight the effect of spinal mGlu4 receptor activation to alleviate the mechanical hypersensitivity observed in inflammatory or neuropathic pain.

One of the most striking findings of our study is that mGlu4 receptors are only influential in painful and pathological conditions after exogenous activation. Physiologically, the mGlu4 receptor seems to be devoid of a tonic role in pain perception as observed when using brief stimuli, such as von Frey hair application or tail immersion. Indeed, thermal sensitivity of mGlu4KO mice is not affected, and they do not differ from WT in their response to innocuous or noxious mechanical stimuli elicited by von Frey hairs on their paw. However, the role of the mGlu4 receptor is revealed by the altered responses of mGlu4KO mice to more noxious stimuli, such as tail pressure, or to an inflammatory agent, such as formalin. Indeed, the nociceptive behavior of mGlu4KO mice is increased in the second phase of the formalin test, suggesting that the lack of mGlu4 receptor may accelerate the development of inflammatory pain. Exogenous mGlu4 activation reduces mechanical allodynia and hyperalgesia in an inflammatory state or in a neuropathic situation but does not modulate acute pain perception after brief stimuli. These results are consistent with the antihyperalgesia observed after activation of Group III mGluRs with Group III selective agonists (Goudet et al., 2008). Antihyperalgesic effects of Group III agonists could be mediated by mGlu4, mGlu7, and/or mGlu8 recep-
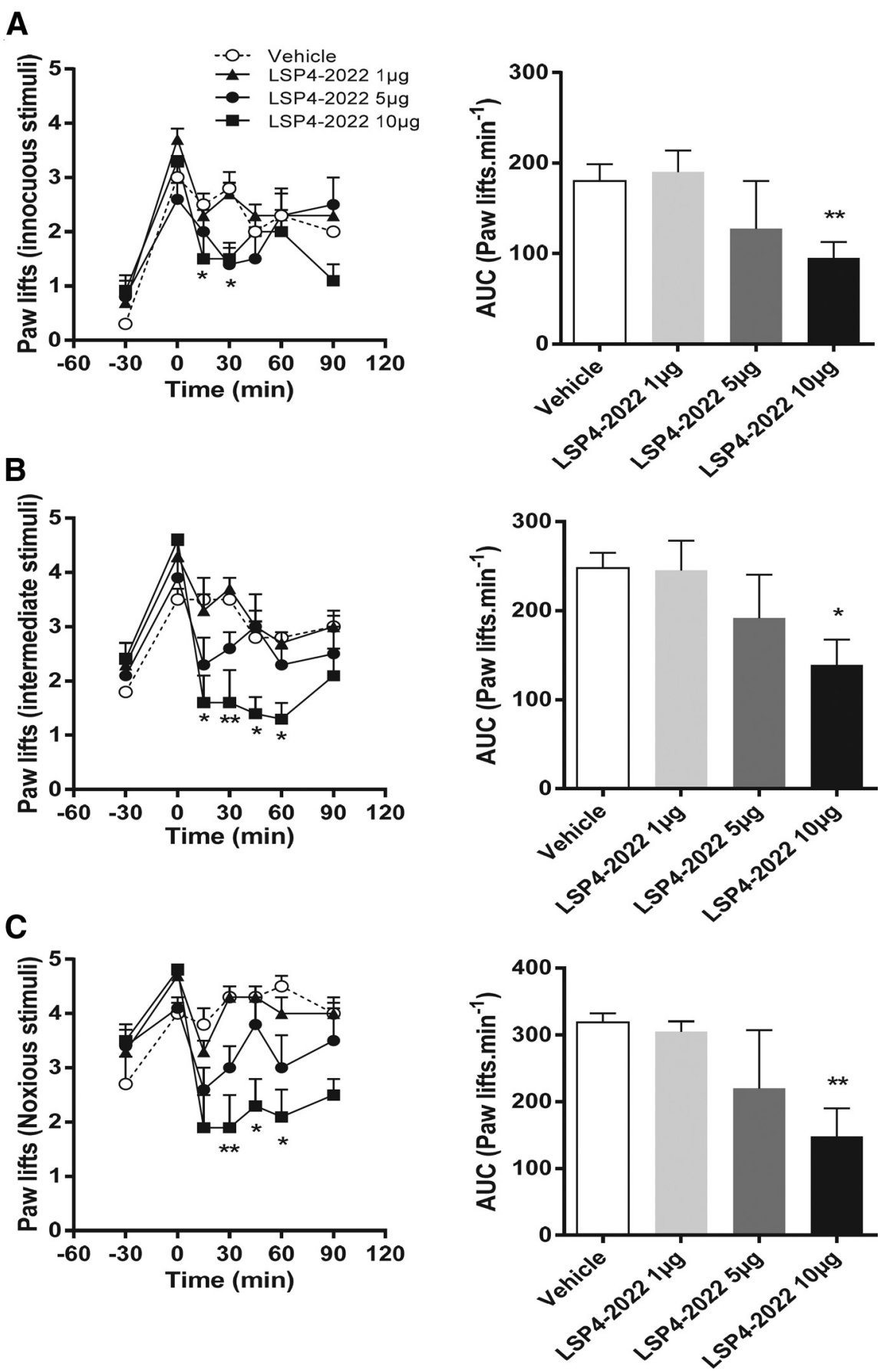

Figure 8. Pharmacological activation of spinal $m G l u 4$ receptors reduces mechanical hypersensitivity induced by inflammation on mice. Time course and area under the curve of mean \pm SEM of the number of paw lifts of five stimulations using von Frey filaments corresponding to innocuous $(\boldsymbol{A})$, intermediate $(\boldsymbol{B})$, and noxious $(\boldsymbol{C})$ bending forces $(0.07,0.6$, and $1.4 \mathrm{~g}$, respectively) on inflamed C57BL/6 mice treated by various doses of LSP4-2022 (as indicated) $240 \mathrm{~min}$ after carrageenan injection $(n=6-8$ animals per group). ${ }^{*} p<0.05$, vehicle versus treated conditions. ${ }^{*} p<0.01$, vehicle versus treated conditions.

tors, which are expressed either in the spinal cord (Ohishi et al., 1995b; Azkue et al., 2001) or in cell bodies of sensory neurons (Carlton and Hargett, 2007). This notwithstanding, the use of selective mGlu4 agonists in this study or allosteric enhancers (Goudet et al., 2008; Wang et al., 2011) suggests that this particular subtype plays a pivotal role in pain modulation. This is further supported by the strong reduction of the antihyperalgesic effect only by exogenous activation in mGlu4KO mice but also after a local and transient knockdown of spinal mGlu4 by AS oligonucleotides in rats. How- 

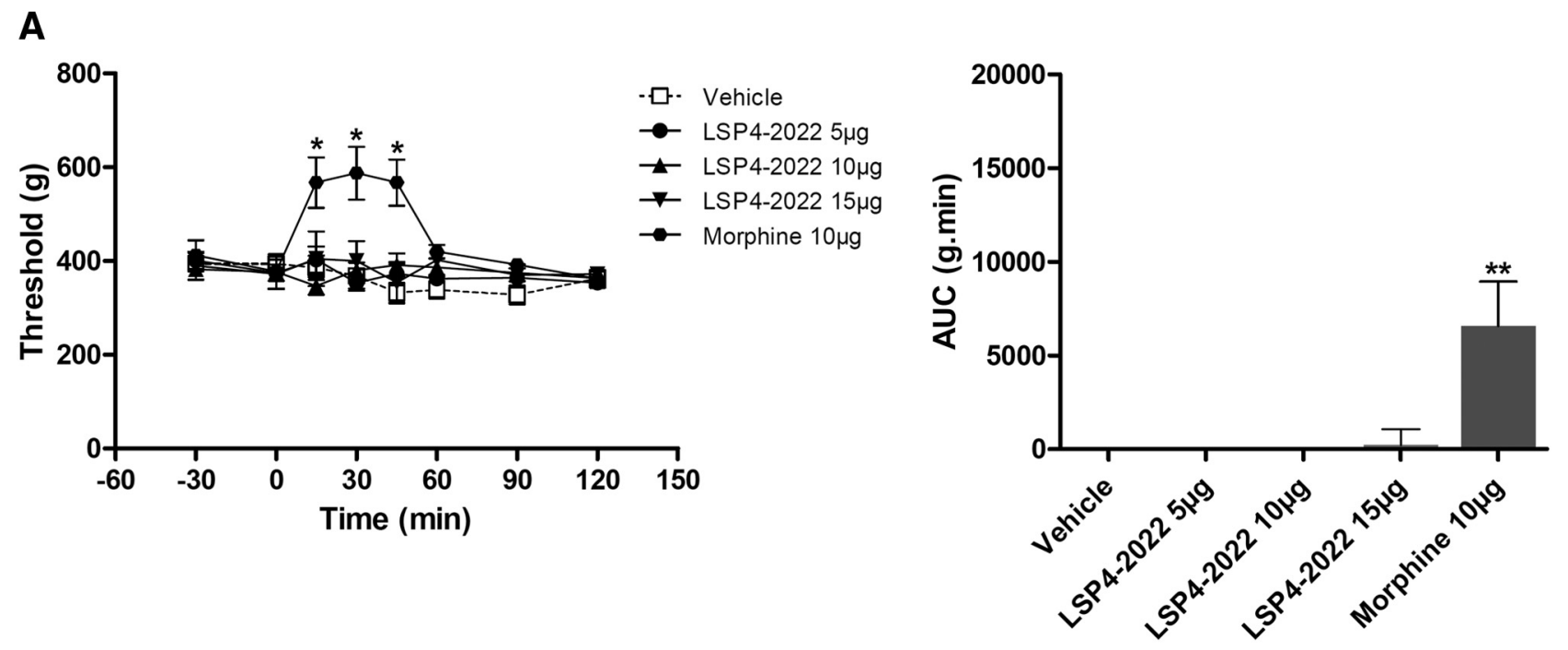

B
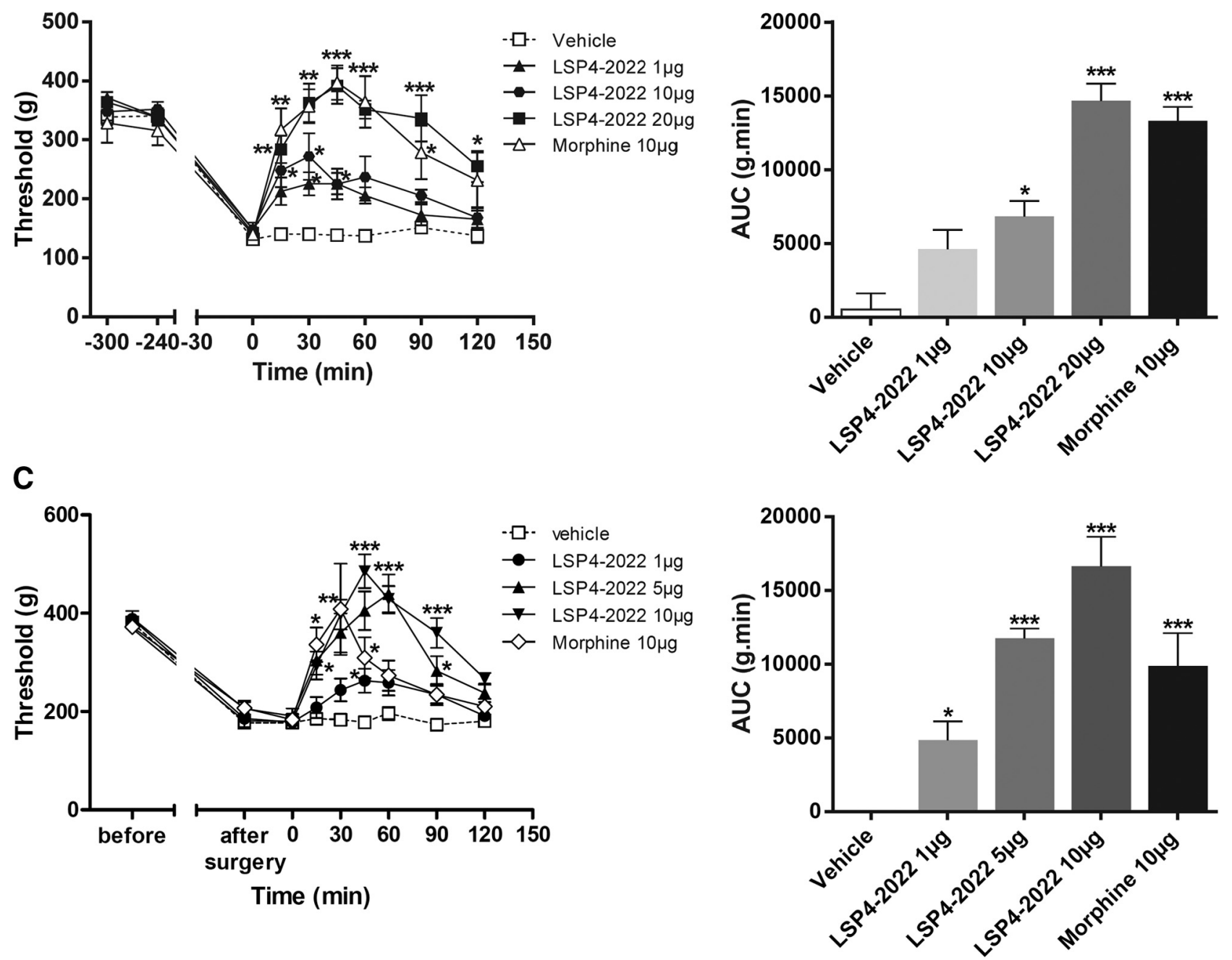

Figure 9. Pharmacological activation of spinal mGlu4 receptors does not modify mechanical sensitivity of naive rats but reduces mechanical hypersensitivity induced by inflammation or neuropathy. Time course of mean \pm SEM of vocalization threshold to paw pressure (in grams) and area under the curve (AUC, g.min) of inflamed rats treated with vehicle, LSP4 -2022 (as indicated in micrograms per rat, i.t.) or morphine (10 $\mu \mathrm{g} / \mathrm{rat}$, i.t.) administered on naive rats $(\boldsymbol{A})$, on inflamed rats $240 \mathrm{~min}$ after carrageenan injection $(\boldsymbol{B})$, and on mononeuropathic rats 2 weeks after ligature of the sciatic nerve $(C)\left(n=6-8\right.$ animals per group). ${ }^{*} p<0.05$, vehicle versus treated conditions. ${ }^{* *} p<0.01$, vehicle versus treated conditions. ${ }^{* * *} p<$ 0.001 , vehicle versus treated conditions. 
A
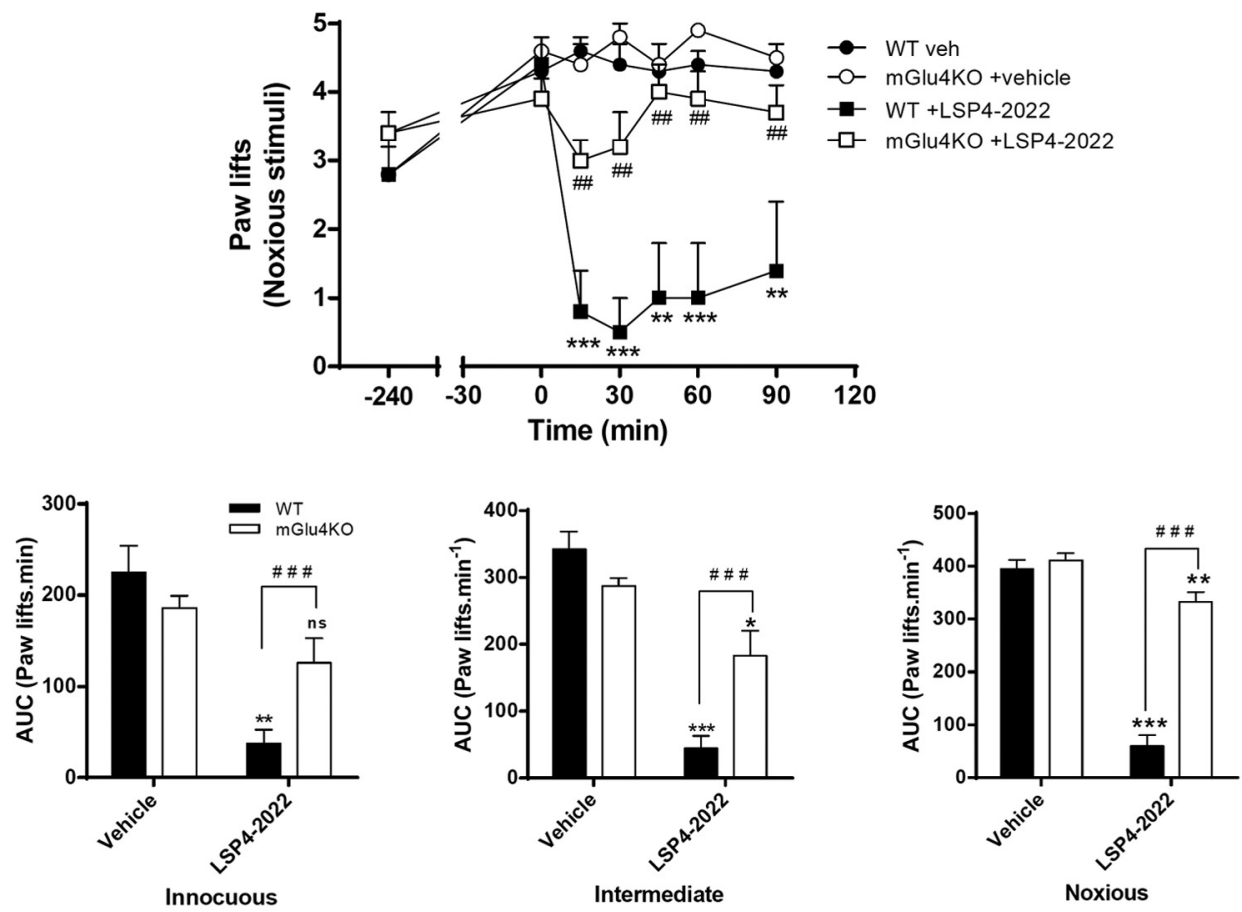

B

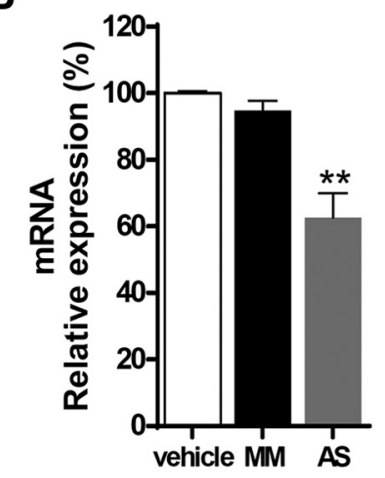

C
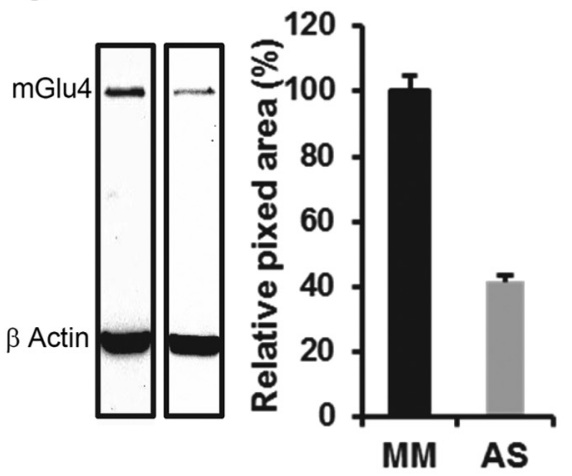

$\mathbf{E}$

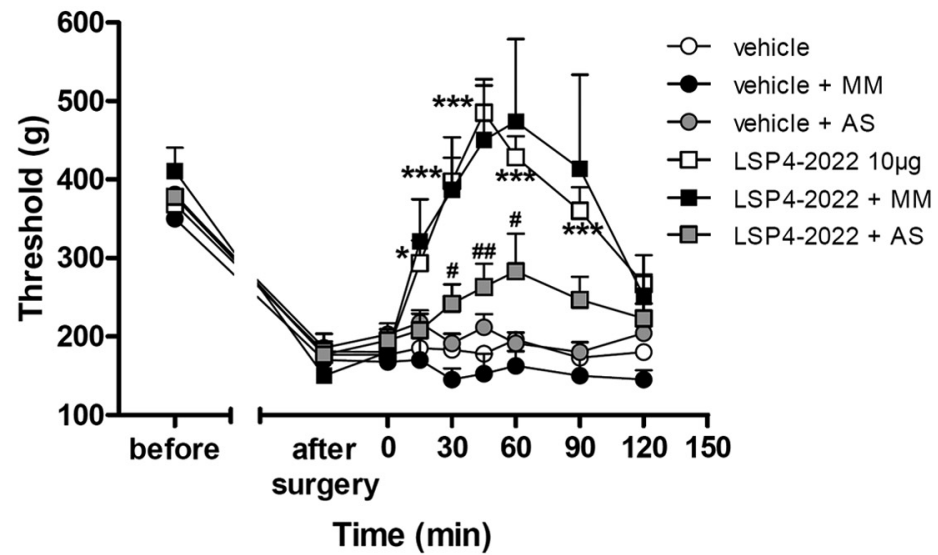

D
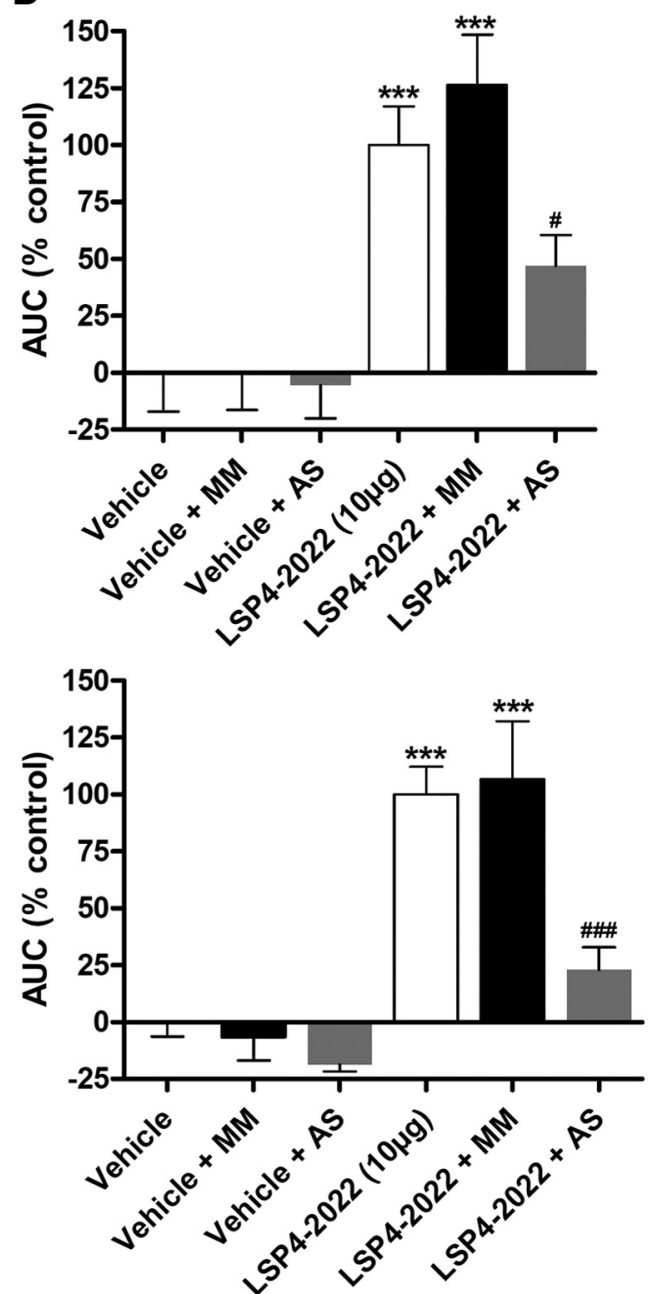

Figure 10. Antihyperalgesia induced by pharmacological activation of spinal $\mathrm{mGlu} 4$ is markedly reduced in $\mathrm{mGlu4KO}$ mice and rats treated by selective $\mathrm{mGlu} 4 \mathrm{AS}$ oligonucleotides. Area under the time course curves of paw lifts after application of von Frey filaments (five stimulations) corresponding to innocuous $(0.07 \mathrm{~g})$, intermediate $(0.6 \mathrm{~g})$, and noxious (1.4 g) (Figure legend continues.) 
A

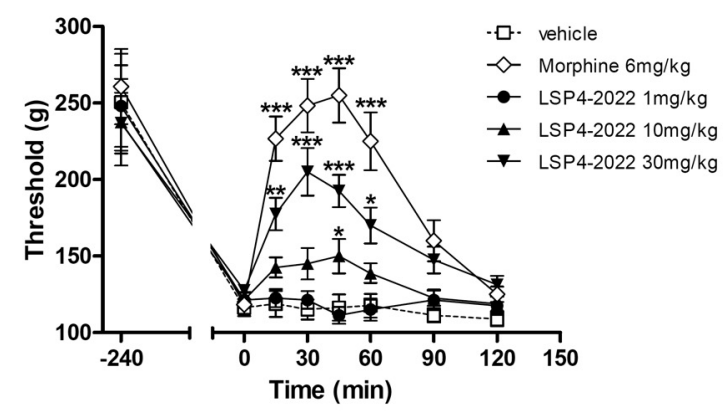

B

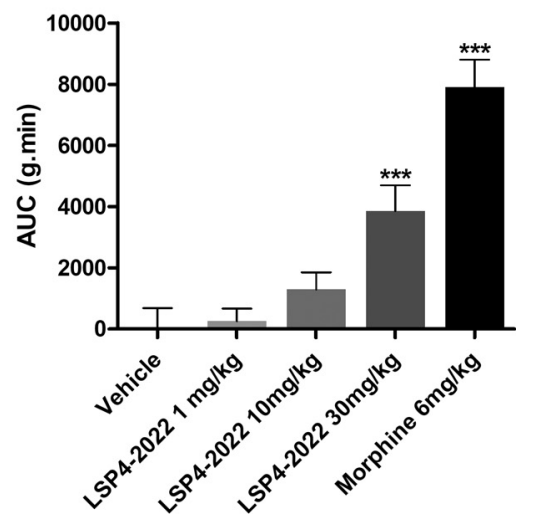

Figure 11. Systemic injection of mGlu4 agonist alleviates mechanical hypersensitivity in inflammation. Results are expressed by the time course curves of mean \pm SEM of vocalization threshold to paw pressure (expressed in grams) in the left panel and by the area under the curve (AUC, g.min) in the right panel. Rats were treated with vehicle, LSP4 -2022 (various doses as indicated in milligrams per kilogram, i.p.), or morphine $\left(6 \mathrm{mg} / \mathrm{kg}\right.$, i.p.) administered 240 min after intraplantar injection of carrageenin ( $n=8$ animals per group). ${ }^{*} p<0.05$ versus vehicle-treated group. ${ }^{* *} p<$ 0.01 versus vehicle-treated group. ${ }^{* * *} p<0.001$ versus vehicle-treated group.

ever, there is still a small but significant antihyperalgesic effect of LSP4-2022 in mGlu4KO mice, suggesting that other Group III mGluRs subtypes may also be involved. Interestingly, we show here that a systemic injection of mGlu4 agonists induces a robust mechanical antihyperalgesia. Together, these results illustrate the therapeutic potential of mGlu4 receptors in a pathological context.

Activation of Group III mGluRs has been shown to decrease firing of spinal cord dorsal horn projection neurons (Chen and Pan, 2005) and reduce spontaneous and evoked spinal synaptic transmission (Zhang et al., 2009; Cui et al., 2011). Our results underline the important role of $\mathrm{mGlu} 4$ in this regulatory process because the selective activation of mGlu4 receptors by LSP42022 replicates the effect obtained by the nonselective Group III agonist L-AP4. Our results further demonstrate that mGlu4 is functionally coupled to Cav2.2 channels in sensory neurons. These channels are mostly expressed in presynaptic terminals of $\mathrm{C}$ - and $\mathrm{A} \delta$-fibers and are key targets against chronic pain, as illustrated by the clinical efficacy of ziconotide or the anticonvulsants gabapentin and pregabalin (Zamponi et al., 2009). Indeed, gabapentin and pregabalin, blockers of the regulatory subunit $\alpha 2 \delta$ of Cav2.2 channels, are effective analgesics for neuropathic pain and are also able to reduce pain and opioid consumption after surgery (Dauri et al., 2009). Furthermore, the Cav2.2 channel blocker, ziconotide, is used to manage severe chronic pain (cancer or neuropathic pain). The identification of a new way to

$\leftarrow$

(Figure legend continued.) bending forces on inflamed mGlu4KO or WT mice treated by LSP4-2022 240 min after injection of carrageenan $(\boldsymbol{A})$ ( $n=7$ animals per group). Top, Illustration of a time course of paw lifts for a noxious bending force. Bottom, Mean \pm SEM of relative antihyperalgesia, expressed as the area under curve of mGlu4K0 or WT mice treated by vehicle and $10 \mu \mathrm{g} \mathrm{LSP4-2022.} \mathrm{Quantification} \mathrm{of} \mathrm{selective} \mathrm{knockdown} \mathrm{of} \mathrm{spinal} \mathrm{Glu4} \mathrm{in} \mathrm{rats} \mathrm{were} \mathrm{treated}$ during $4 \mathrm{~d}$ by vehicle, scrambled control, or mGlu4 receptor targeting AS oligonucleotides by measuring DRG mGlu4 mRNA level by qRT-PCR $(\boldsymbol{B})$ or spinal protein level by Western blot (C). Effect of mGlu4 receptor knockdown on LSP4-2022-mediated antihyperalgesia in inflamed rats (D) ( $n=7$ animals per group) and neuropathic rats $(\boldsymbol{E})(n=8$ animals per group). Left, Time course curves of mean \pm SEM of vocalization threshold to paw pressure (expressed in grams). Right, Mean \pm SEM of relative antihyperalgesia, expressed as percentage of the area

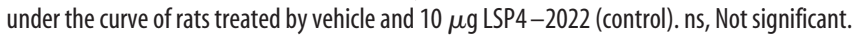
${ }^{*} p<0.05$ versus vehicle-treated group. ${ }^{* *} p<0.01$ versus vehicle-treated group. ${ }^{* * *} p<$ 0.001 versus vehicle-treated group. \#p $<0.05$ versus corresponding LSP4-2022 treated WT groups. \#\# $<0.01$ versus corresponding LSP4-2022 treated WT groups. \#\#\# $<0.001$ versus corresponding LSP4-2022 treated WT groups. inhibit Cav2.2 at the spinal cord level by activating mGlu4 receptors may lead to improved therapeutic strategies, as illustrated by Brittain et al. (2011). Interestingly, we also show here that mGlu4-induced inhibition of glutamatergic neurotransmission is reinforced in spinal cord slices from inflamed mice. This is consistent with the observation that the ability of Group III mGluRs to control the excess of excitatory transmission is reinforced in spinal cord of neuropathic pain animal models (Zhang et al., 2009). This may reflect both the synaptic plasticity associated with central sensitization observed in chronic pain and the use-dependent activity of Group III mGluRs, mGlu4 receptors in particular. The latter point will be further discussed below. The molecular remodeling that takes place under chronic pain conditions notably includes overexpression of Cav2.2 channels and its regulatory subunits (Lu et al., 2010), could explain the reinforcement of mGlu4 inhibitory effect.

How is it that mGlu4 receptors are only modulating painful or pathological pain states and not pain perception when using brief stimuli in naive animals? First, this could be due to the localization of the mGlu4 receptor in a particular subset of sensory neurons and in PKC $\gamma$-expressing interneurons, as suggested by our results obtained after rhizotomy and data from of imunostaining studies. We localized some mGlu4 receptors to the sensory terminals of unmyelinated fibers in the inner lamina II of the dorsal horn of spinal cord. Although there is some mGlu4 receptor staining in peptidergic and nonpeptidergic $\mathrm{C}$ fibers in which the role in nociception is well known (Basbaum et al., 2009; Todd, 2010), most of the labeling is located in a subset of C-LTMR expressing VGLUT3. While normally devoted to the sensing of pleasant touch in humans, these fibers are involved in mechanical hypersensitivity in animal models of inflammation or neuropathy (Löken et al., 2009; Seal et al., 2009; Li et al., 2011). Moreover, mGlu4 immunoreactivity overlaps in great part with PKC $\gamma$ immunoreactivity. PKC $\gamma$-expressing interneurons are excitatory interneurons located where low-threshold mechanoreceptive and nociceptive inputs terminate and play a key role in the processing of tactile inputs both in physiological and pathological conditions (Malmberg et al., 1997; Polgár et al., 1999; Neumann et al., 2008) These interneurons are activated by innocuous stimuli in physiological conditions (Neumann et al., 2008; Li et al., 2011) but are thought to mediate pain hypersensitivity induced by injury (Malmberg et al., 1997; Polgár et al., 1999), probably 
through loss of inhibition via inhibitory interneurons (Miraucourt et al., 2007; Lu et al., 2013). Thus, the presence of mGlu4 in these neurons could explain why they modulate mechanical sensitivity in chronic pain conditions without affecting acute mechanical pain. Combined with the fact that mGlu4 activation is able to regulate eEPSCs in spinal cord slices from naive animals, our results also suggest that, in physiological conditions, mGlu4 receptors could modulate touch modality instead of pain. Further experiments are required to clarify this point.

A second possible explanation for the observation of the mGlu4 receptor role in pathological conditions may reside in the use-dependent mode of action of these receptors. mGlu4 receptors are present in the active zone of the presynaptic element where the neurotransmitters are released (Ferraguti and Shigemoto, 2006). From a mechanistic point of view, the role of Group III mGluRs autoreceptors, including mGlu4, is to prevent an overactivity of the glutamatergic system (Nicoletti et al., 2011). Use-dependent release of glutamate induces an activation of presynaptic Group III mGluRs and leads to a negative retrocontrol of synaptic activity. This has previously been described in different brain areas (for review, see Cartmell and Schoepp, 2000). According to this hypothesis, in the dorsal horn of the spinal cord, synaptic glutamate release would not be sufficient to ensure Group III mGluRs activation under basal conditions; therefore, these receptors would not modulate responses to short nociceptive stimuli. On the other hand, upon more noxious or longer stimuli, glutamate release from sensory neurons should increase, activating these presynaptic receptors, which in turn would downregulate sensory neuron activity. Several studies have now confirmed this view. First, in the dorsal horn of spinal cord, an increase of glutamate release from sensory neurons induced by noxious stimuli has been reported in inflammatory or neuropathic conditions using in vivo microdialysis (Sluka and Westlund, 1992; Yang et al., 1996; Coderre et al., 2005). Furthermore, in these conditions, activation of Group II/III mGluR attenuates noxious stimulus-induced glutamate release in spinal cord dorsal horn (Sluka and Westlund, 1992; Yang et al., 1996; Kumar et al., 2010) and prevents overactivity of sensory neurons (Carlton et al., 2011). Finally, regulation of enhanced nociception can also be achieved after an exogenous stimulation of Group III mGluRs by pharmacologic agents. Indeed, agonists of Group III mGluRs reduce the resulting enhanced nociception (Fisher et al., 2002; Chen and Pan, 2005; Goudet et al., 2008; Kumar et al., 2010). In this study, we demonstrate that selective activation of mGlu4 replicates the action of nonselective Group III mGluRs agonists, confirming the important role of this receptor. Together, present results suggest that the antihyperalgesic activity of exogenous activation of mGlu4 may result both from the localization of mGlu4 receptors in sensory and spinal neurons that convey pain solely in pathological context and from the use-dependent mode of action of this receptor only in instances where glutamatergic transmission is overactivated.

In conclusion, mGlu4 receptors seem to be promising targets for the treatment of chronic pain. Indeed, while leaving acute pain perception in naive individuals unchanged, mGlu4 receptors are able to downregulate the abnormal glutamatergic activity seen in pathological pain contexts and consequently reduce the associated hypersensitivity to mechanical stimuli. Of major interest, antihyperalgesia is not only observed when the drug is injected locally, but also after systematic administration. The corollary of this matter is that mGlu4 agonists, such as the prototypal LSP4-2022 used in this study, may be considered as po- tential analgesics and underscores the therapeutic interest of developing novel agonists or enhancers of mGlu4 receptors.

\section{References}

Acher F, Pin JP, Goudet C, Eschalier A, Busserolles J, Rigault D, Lemasson IA, Cesarini S, Commare B (2012) Hypophosphorous acid derivatives having antihyperalgesic activity and biological applications thereof. Patent WO2012/156931.

Azkue JJ, Murga M, Fernández-Capetillo O, Mateos JM, Elezgarai I, Benítez R, Osorio A, Díez J, Puente N, Bilbao A, Bidaurrazaga A, Kuhn R, Grandes P (2001) Immunoreactivity for the Group III metabotropic glutamate receptor subtype mGluR4a in the superficial laminae of the rat spinal dorsal horn. J Comp Neurol 430:448-457. CrossRef Medline

Basbaum AI, Bautista DM, Scherrer G, Julius D (2009) Cellular and molecular mechanisms of pain. Cell 139:267-284. CrossRef Medline

Bennett GJ, Xie YK (1988) A peripheral mononeuropathy in rat that produces disorders of pain sensation like those seen in man. Pain 33:87-107. CrossRef Medline

Bouhassira D, Lantéri-Minet M, Attal N, Laurent B, Touboul C (2008) Prevalence of chronic pain with neuropathic characteristics in the general population. Pain 136:380-387. CrossRef Medline

Bourinet E, Alloui A, Monteil A, Barrère C, Couette B, Poirot O, Pages A, McRory J, Snutch TP, Eschalier A, Nargeot J (2005) Silencing of the Cav3.2 T-type calcium channel gene in sensory neurons demonstrates its major role in nociception. EMBO J 24:315-324. CrossRef Medline

Breivik H, Collett B, Ventafridda V, Cohen R, Gallacher D (2006) Survey of chronic pain in Europe: prevalence, impact on daily life, and treatment. Eur J Pain 10:287-333. CrossRef Medline

Brittain JM, Duarte DB, Wilson SM, Zhu W, Ballard C, Johnson PL, Liu N, Xiong W, Ripsch MS, Wang Y, Fehrenbacher JC, Fitz SD, Khanna M, Park CK, Schmutzler BS, Cheon BM, Due MR, Brustovetsky T, Ashpole NM, Hudmon A, et al. (2011) Suppression of inflammatory and neuropathic pain by uncoupling CRMP-2 from the presynaptic $\mathrm{Ca}(2)(+)$ channel complex. Nat Med 17:822-829. CrossRef Medline

Carlton SM, Hargett GL (2007) Colocalization of metabotropic glutamate receptors in rat dorsal root ganglion cells. J Comp Neurol 501:780-789. CrossRef Medline

Carlton SM, Zhou S, Govea R, Du J (2011) Group II/III metabotropic glutamate receptors exert endogenous activity-dependent modulation of TRPV1 receptors on peripheral nociceptors. J Neurosci 31:12727-12737. CrossRef Medline

Cartmell J, Schoepp DD (2000) Regulation of neurotransmitter release by metabotropic glutamate receptors. J Neurochem 75:889-907. CrossRef Medline

Chen SR, Pan HL (2005) Distinct roles of Group III metabotropic glutamate receptors in control of nociception and dorsal horn neurons in normal and nerve-injured rats. J Pharmacol Exp Ther 312:120-126. CrossRef Medline

Chiechio S, Nicoletti F (2012) Metabotropic glutamate receptors and the control of chronic pain. Curr Opin Pharmacol 12:28-34. CrossRef Medline

Coderre TJ, Kumar N, Lefebvre CD, Yu JS (2005) Evidence that gabapentin reduces neuropathic pain by inhibiting the spinal release of glutamate. J Neurochem 94:1131-1139. CrossRef Medline

Cui L, Kim YR, Kim HY, Lee SC, Shin HS, Szabó G, Erdélyi F, Kim J, Kim SJ (2011) Modulation of synaptic transmission from primary afferents to spinal substantia gelatinosa neurons by Group III mGluRs in GAD65EGFP transgenic mice. J Neurophysiol 105:1102-1111. CrossRef Medline

Dauri M, Faria S, Gatti A, Celidonio L, Carpenedo R, Sabato AF (2009) Gabapentin and pregabalin for the acute post-operative pain management: a systematic-narrative review of the recent clinical evidences. Curr Drug Targets 10:716-733. CrossRef Medline

Eckstein F, Cassel D, Levkovitz H, Lowe M, Selinger Z (1979) Guanosine 5'-O(2-thiodiphosphate): an inhibitor of adenylate cyclase stimulation by guanine nucleotides and fluoride ions. J Biol Chem 254:9829-9834. Medline

Fan QQ, Li L, Wang WT, Yang X, Suo ZW, Hu XD (2013) Activation of alpha2 adrenoceptors inhibited NMDA receptor-mediated nociceptive transmission in spinal dorsal horn of mice with inflammatory pain. Neuropharmacology 77C:185-192. CrossRef Medline

Ferraguti F, Shigemoto R (2006) Metabotropic glutamate receptors. Cell Tissue Res 326:483-504. CrossRef Medline

Finnerup NB, Sindrup SH, Jensen TS (2010) The evidence for pharmacological treatment of neuropathic pain. Pain 150:573-581. CrossRef Medline

Fisher K, Lefebvre C, Coderre TJ (2002) Antinociceptive effects following 
intrathecal pretreatment with selective metabotropic glutamate receptor compounds in a rat model of neuropathic pain. Pharmacol Biochem Behav 73:411-418. CrossRef Medline

Goudet C, Chapuy E, Alloui A, Acher F, Pin JP, Eschalier A (2008) Group III metabotropic glutamate receptors inhibit hyperalgesia in animal models of inflammation and neuropathic pain. Pain 137:112-124. CrossRef Medline

Goudet C, Magnaghi V, Landry M, Nagy F, Gereau RW 4th, Pin JP (2009) Metabotropic receptors for glutamate and GABA in pain. Brain Res Rev 60:43-56. CrossRef Medline

Goudet C, Vilar B, Courtiol T, Deltheil T, Bessiron T, Brabet I, Oueslati N, Rigault D, Bertrand HO, McLean H, Daniel H, Amalric M, Acher F, Pin JP (2012) A novel selective metabotropic glutamate receptor 4 agonist reveals new possibilities for developing subtype selective ligands with therapeutic potential. FASEB J 26:1682-1693. CrossRef Medline

Heinke B, Balzer E, Sandkühler J (2004) Pre- and postsynaptic contributions of voltage-dependent $\mathrm{Ca}^{2+}$ channels to nociceptive transmission in rat spinal lamina I neurons. Eur J Neurosci 19:103-111. CrossRef Medline

Holz GG 4th, Rane SG, Dunlap K (1986) GTP-binding proteins mediate transmitter inhibition of voltage-dependent calcium channels. Nature 319:670-672. CrossRef Medline

Kumar N, Laferriere A, Yu JS, Poon T, Coderre TJ (2010) Metabotropic glutamate receptors (mGluRs) regulate noxious stimulus-induced glutamate release in the spinal cord dorsal horn of rats with neuropathic and inflammatory pain. J Neurochem 114:281-290. CrossRef Medline

Latremoliere A, Woolf CJ (2009) Central sensitization: a generator of pain hypersensitivity by central neural plasticity. J Pain 10:895-926. CrossRef Medline

Li L, Rutlin M, Abraira VE, Cassidy C, Kus L, Gong S, Jankowski MP, Luo W, Heintz N, Koerber HR, Woodbury CJ, Ginty DD (2011) The functional organization of cutaneous low-threshold mechanosensory neurons. Cell 147:1615-1627. CrossRef Medline

Löken LS, Wessberg J, Morrison I, McGlone F, Olausson H (2009) Coding of pleasant touch by unmyelinated afferents in humans. Nat Neurosci 12:547-548. CrossRef Medline

Lu SG, Zhang XL, Luo ZD, Gold MS (2010) Persistent inflammation alters the density and distribution of voltage-activated calcium channels in subpopulations of rat cutaneous DRG neurons. Pain 151:633-643. CrossRef Medline

Lu Y, Dong H, Gao Y, Gong Y, Ren Y, Gu N, Zhou S, Xia N, Sun YY, Ji RR, Xiong L (2013) A feed-forward spinal cord glycinergic neural circuit gates mechanical allodynia. J Clin Invest 123:4050-4062. CrossRef Medline

Malmberg AB, Chen C, Tonegawa S, Basbaum AI (1997) Preserved acute pain and reduced neuropathic pain in mice lacking PKCgamma. Science 278:279-283. CrossRef Medline

Mestre C, Pélissier T, Fialip J, Wilcox G, Eschalier A (1994) A method to perform direct transcutaneous intrathecal injection in rats. J Pharmacol Toxicol Methods 32:197-200. CrossRef Medline

Micó JA, Ardid D, Berrocoso E, Eschalier A (2006) Antidepressants and pain. Trends Pharmacol Sci 27:348-354. CrossRef Medline

Mills CD, Johnson KM, Hulsebosch CE (2002) Role of Group II and Group III metabotropic glutamate receptors in spinal cord injury. Exp Neurol 173:153-167. CrossRef Medline

Miraucourt LS, Dallel R, Voisin DL (2007) Glycine inhibitory dysfunction turns touch into pain through PKCgamma interneurons. PloS One 2:e1116. CrossRef Medline

Neugebauer V (2007) Glutamate receptor ligands. Handb Exp Pharmacol 177:217-249. Medline

Neumann S, Braz JM, Skinner K, Llewellyn-Smith IJ, Basbaum AI (2008) Innocuous, not noxious, input activates PKCgamma interneurons of the spinal dorsal horn via myelinated afferent fibers. J Neurosci 28:79367944. CrossRef Medline

Nicoletti F, Bockaert J, Collingridge GL, Conn PJ, Ferraguti F, Schoepp DD, Wroblewski JT, Pin JP (2011) Metabotropic glutamate receptors: from the workbench to the bedside. Neuropharmacology 60:1017-1041. CrossRef Medline

Niswender CM, Conn PJ (2010) Metabotropic glutamate receptors: physiology, pharmacology, and disease. Annu Rev Pharmacol Toxicol 50:295322. CrossRef Medline

Ohishi H, Akazawa C, Shigemoto R, Nakanishi S, Mizuno N (1995a) Distributions of the mRNAs for L-2-amino-4-phosphonobutyrate-sensitive metabotropic glutamate receptors, mGluR4 and mGluR7, in the rat brain. J Comp Neurol 360:555-570. CrossRef Medline

Ohishi H, Nomura S, Ding YQ, Shigemoto R, Wada E, Kinoshita A, Li JL,
Neki A, Nakanishi S, Mizuno N (1995b) Presynaptic localization of a metabotropic glutamate receptor, mGluR7, in the primary afferent neurons: an immunohistochemical study in the rat. Neurosci Lett 202:85-88. CrossRef Medline

Ospina M, Harstall C (2002) Prevalence of chronic pain: an overview. In: Health technology assessment (Research Alberta Heritage Foundation for Medical Research, ed). Edmonton, AB: Research Alberta Heritage Foundation for Medical Research.

Pekhletski R, Gerlai R, Overstreet LS, Huang XP, Agopyan N, Slater NT, Abramow-Newerly W, Roder JC, Hampson DR (1996) Impaired cerebellar synaptic plasticity and motor performance in mice lacking the mGluR4 subtype of metabotropic glutamate receptor. J Neurosci 16 : 6364-6373. Medline

Pitsch J, Schoch S, Gueler N, Flor PJ, van der Putten H, Becker AJ (2007) Functional role of mGluR1 and mGluR4 in pilocarpine-induced temporal lobe epilepsy. Neurobiol Dis 26:623-633. CrossRef Medline

Polgár E, Fowler JH, McGill MM, Todd AJ (1999) The types of neuron which contain protein kinase $\mathrm{C}$ gamma in rat spinal cord. Brain Res 833:71-80. CrossRef Medline

Randall LO, Selitto JJ (1957) A method for measurement of analgesic activity on inflamed tissue. Arch Int Pharmacodyn Ther 111:409-419. Medline

Rebola N, Lujan R, Cunha RA, Mulle C (2008) Adenosine A2A receptors are essential for long-term potentiation of NMDA-EPSCs at hippocampal mossy fiber synapses. Neuron 57:121-134. CrossRef Medline

Seal RP, Wang X, Guan Y, Raja SN, Woodbury CJ, Basbaum AI, Edwards RH (2009) Injury-induced mechanical hypersensitivity requires C-low threshold mechanoreceptors. Nature 462:651-655. CrossRef Medline

Selvam C, Oueslati N, Lemasson IA, Brabet I, Rigault D, Courtiol T, Cesarini S, Triballeau N, Bertrand HO, Goudet C, Pin JP, Acher FC (2010) A virtual screening hit reveals new possibilities for developing Group III metabotropic glutamate receptor agonists. J Med Chem 53:2797-2813. CrossRef Medline

Sluka KA, Westlund KN (1992) An experimental arthritis in rats: dorsal horn aspartate and glutamate increases. Neurosci Lett 145:141-144. CrossRef Medline

Todd AJ (2010) Neuronal circuitry for pain processing in the dorsal horn. Nat Rev Neurosci 11:823-836. CrossRef Medline

tom Dieck S, Sanmartí-Vila L, Langnaese K, Richter K, Kindler S, Soyke A, Wex H, Smalla KH, Kämpf U, Fränzer JT, Stumm M, Garner CC, Gundelfinger ED (1998) Bassoon, a novel zinc-finger CAG/glutaminerepeat protein selectively localized at the active zone of presynaptic nerve terminals. J Cell Biol 142:499-509. CrossRef Medline

Varney MA, Gereau RW 4th (2002) Metabotropic glutamate receptor involvement in models of acute and persistent pain: prospects for the development of novel analgesics. Curr Drug Targets CNS Neurol Disord 1:283-296. CrossRef Medline

Verhaak PF, Kerssens JJ, Dekker J, Sorbi MJ, Bensing JM (1998) Prevalence of chronic benign pain disorder among adults: a review of the literature. Pain 77:231-239. CrossRef Medline

Wang H, Jiang W, Yang R, Li Y (2011) Spinal metabotropic glutamate receptor 4 is involved in neuropathic pain. Neuroreport 22:244-248. CrossRef Medline

Wiedenmann B, Franke WW (1985) Identification and localization of synaptophysin, an integral membrane glycoprotein of $\mathrm{Mr} 38,000$ characteristic of presynaptic vesicles. Cell 41:1017-1028. CrossRef Medline

Yang K, Takeuchi K, Wei F, Dubner R, Ren K (2011) Activation of Group I mGlu receptors contributes to facilitation of NMDA receptor membrane current in spinal dorsal horn neurons after hind paw inflammation in rats. Eur J Pharmacol 670:509-518. CrossRef Medline

Yang LC, Marsala M, Yaksh TL (1996) Characterization of time course of spinal amino acids, citrulline and $\mathrm{PGE}_{2}$ release after carrageenan/kaolininduced knee joint inflammation: a chronic microdialysis study. Pain 67:345-354. CrossRef Medline

Zamponi GW, Lewis RJ, Todorovic SM, Arneric SP, Snutch TP (2009) Role of voltage-gated calcium channels in ascending pain pathways. Brain Res Rev 60:84-89. CrossRef Medline

Zhang HM, Chen SR, Pan HL (2009) Effects of activation of Group III metabotropic glutamate receptors on spinal synaptic transmission in a rat model of neuropathic pain. Neuroscience 158:875-884. CrossRef Medline

Zimmermann M (1983) Ethical guidelines for investigations of experimental pain in conscious animals. Pain 16:109-110. CrossRef Medline 